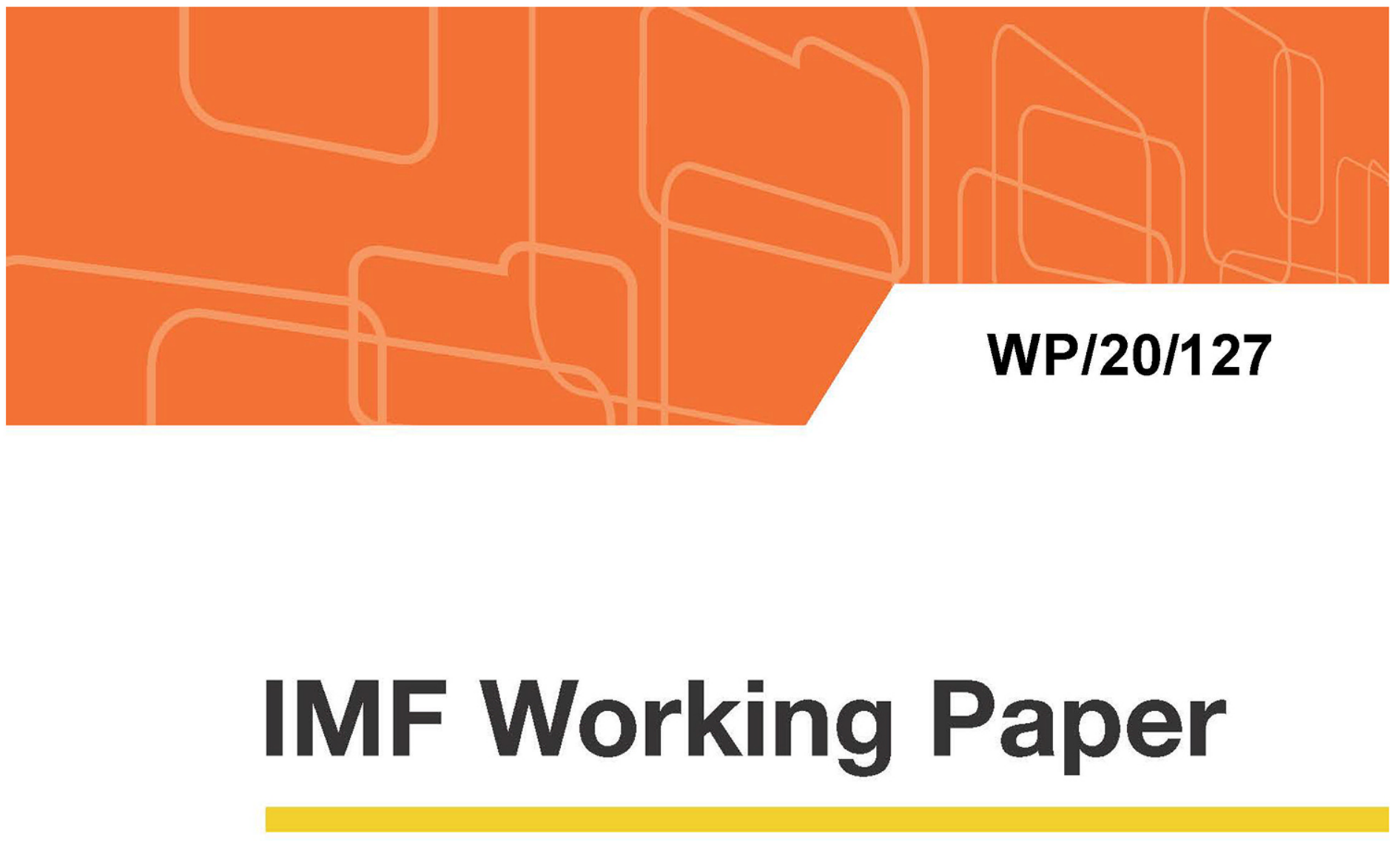

\title{
Accounting for Cloud Computing in the National Accounts
}

by Andrew Baer, Kwangwon Lee, and James Tebrake

IMF Working Papers describe research in progress by the author(s) and are published to elicit comments and to encourage debate. The views expressed in IMF Working Papers are those of the author(s) and do not necessarily represent the views of the IMF, its Executive Board, or IMF management. 


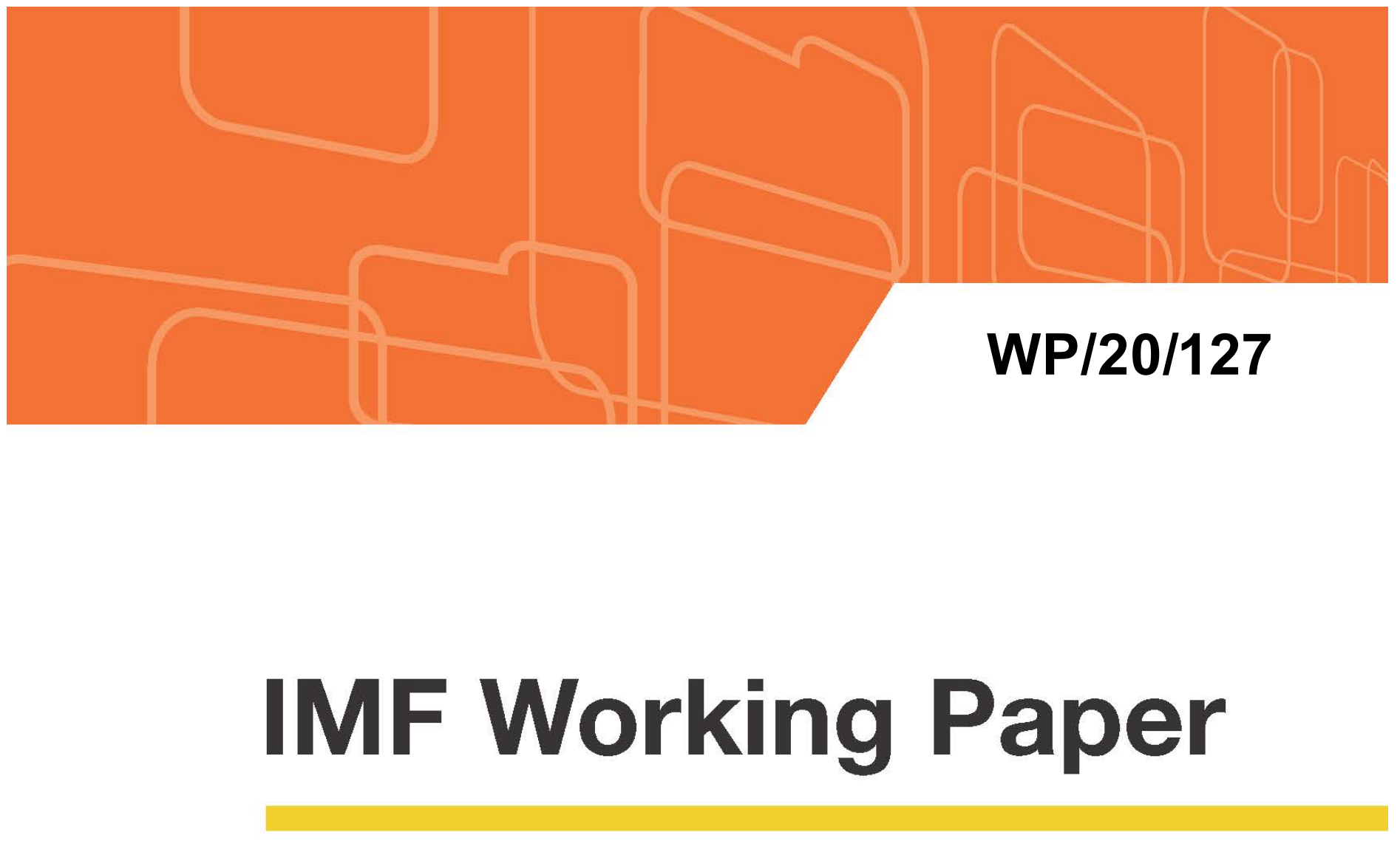

\section{Accounting for Cloud Computing in the National Accounts}

by Andrew Baer, Kwangwon Lee, and James Tebrake

IMF Working Papers describe research in progress by the author(s) and are published to elicit comments and to encourage debate. The views expressed in IMF Working Papers are those of the author(s) and do not necessarily represent the views of the IMF, its Executive Board, or IMF management.

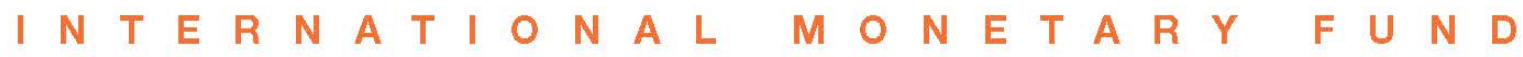




\title{
IMF Working Paper
}

Statistics Department

\author{
Accounting for Cloud Computing in the National Accounts ${ }^{1}$ \\ Prepared by Andrew Baer, Kwangwon Lee, and James Tebrake \\ Authorized for distribution by Gabriel Quiros-Romero
}

July 2020

\begin{abstract}
IMF Working Papers describe research in progress by the author(s) and are published to elicit comments and to encourage debate. The views expressed in IMF Working Papers are those of the author(s) and do not necessarily represent the views of the IMF, its Executive Board, or IMF management.
\end{abstract}

\begin{abstract}
Digitalization and the innovative use of digital technologies is changing the way we work, learn, communicate, buy and sell products. One emerging digital technology of growing importance is cloud computing. More and more businesses, governments and households are purchasing hardware and software services from a small number of large cloud computing providers. This change is having an impact on how macroeconomic data are compiled and how they are interpreted by users. Specifically, this is changing the information and communication technology (ICT) investment pattern from one where ICT investment was diversified across many industries to a more concentrated investment pattern. Additionally, this is having an impact on cross-border flows of commercial services since the cloud service provider does not need to be located in the same economic territory as the purchaser of cloud services. This paper will outline some of the methodological and compilation challenges facing statisticians and analysts, provide some tools that can be used to overcome these challenges and highlight some of the implications these changes are having on the way users of national accounts data look at investment and trade in commercial services.

JEL Classification Numbers: E01, E2, E3, L96

Keywords: cloud computing, information and communication technology, national accounts Author's E-Mail Address: ABaer@,imf.org; adrian01.22@,gmail.com; JTebrake@imf.org;

\footnotetext{
${ }^{1}$ We would like to thank Marshall Reinsdorf for his detailed comments on an earlier draftof this paper. We are a lso gra teful to our colleagues Gabriel Quiros, Carlos Sa nchez-Munoz, Robert Dippelsman, Jennifer Ribarsky, and Marcelo Dinenzon for their support and suggestions. Finally, we extend our thanks to Da vid Wasshausen, Dylan Rassier, Greg Punchak, and Hussein Charara from the U.S. Bureau ofEconomic Analysis for providing comments and helpful information based on their experiences.
} 
Contents

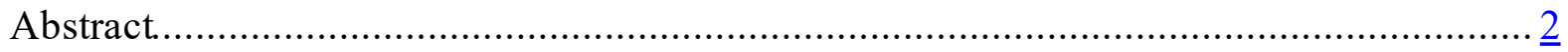

I. Background ................................................................................................. 4

II. Cloud Computing Services ..................................................................... $\underline{4}$

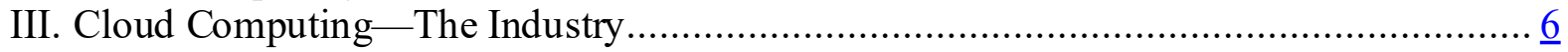

IV. The Challenges Cloud Computing Poses for National Accountants........................ 10

V. Updating Our Toolbox to Account For The Cloud................................................ 16

VI. Updating Classification Systems................................................................ $\frac{17}{19}$

VII. New Data Sources ..................................................................................... $\frac{19}{24}$

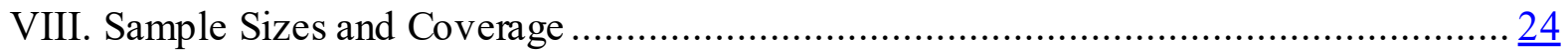

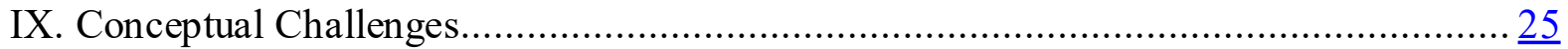

X. What Difference This Makes To Our Users..................................................... $\frac{27}{30}$

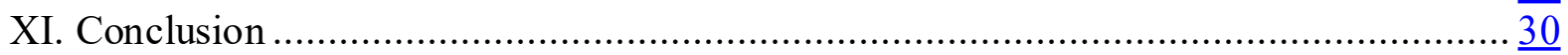

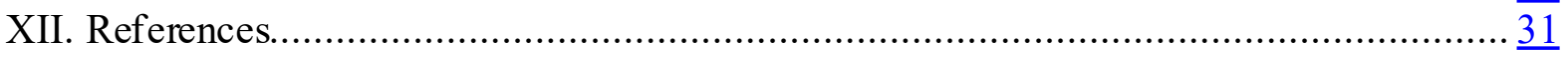

Tables

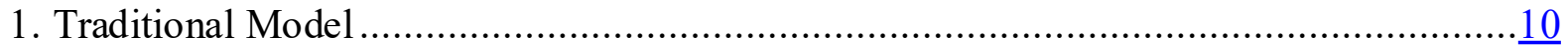

2. Cloud Model............................................................................................. $\frac{11}{12}$

3. Cloud Model with Rationalization .............................................................

4. Cloud Model with Rationalization and Foreign Provision .....................................13

5. Cloud Model with Rationalization and Foreign Provision with Multiple Data Centers..... 15

6. Data Needed to Measure Cloud Computing....................................................

Figures

1. Global Cloud Computing Market Forecast........................................................

2. Global laaS Cloud Computing Market Share.......................................................... $\frac{7}{8}$

3. Share of Businesses Purchasing Cloud Computing Services in OECD Countries............... $\underline{8}$

4. Businesses Purchasing Cloud Computing Services (2018) .......................................... 9

5. Share of Businesses Purchasing Cloud Computing Services in OECD Countries.............. $\underline{9}$

6. Services Producer Price Index for Entrusted Computing Services ...............................23

7. Official U.S. PPI for Cloud-Related Activities and Byrne, Corrado, Sichel Indexes for Selected AWS Products ..................................................................................... 24

8. Relative Size of Computer Services Export in OECD Countries ................................ $\frac{28}{28}$

9. Computer Services Export Ratio of Major Exporters ........................................... $\frac{28}{29}$

10. Portion of Major Server (HS847150) Importers....................................................29

11. Share of Server Imports in Total Imports.................................................... 


\section{BACKGROUND}

Digitalization and the innovative use of digital technologies is changing the way we work, learn, communicate and buy and sell products. One emerging digital technology of growing importance is cloud computing. More and more businesses, governments and households are purchasing hardware and software services from a small number of large cloud computing providers. This change is having an impact on how macroeconomic data are compiled and how they are interpreted by users.

Specifically, this has the potential to change the information and communication technology (ICT) investment pattern from one where ICT investment was diversified across many industries to a more concentrated ICT investment pattern. Additionally, cloud computing is having an impact on cross-border flows of commercial services since the cloud service provider does not need to be in the same economic territory as the purchaser of the cloud services. This paper outlines some of the methodological and compilation challenges facing economic statisticians when 'accounting for the cloud,' provides some suggested tools that can be used to overcome these challenges and highlights some of the implications these changes are having on the way users of economic statistics interpret investment, trade and productivity.

\section{Cloud Computing Services}

Cloud computing services provide customers with on-demand Internet access to ICT resources, such as computing power, data storage capacity, software services and operating system functionality. These resources run on servers, storage devices, and networking equipment housed in data centers operated by the cloud computing provider. The service provider is responsible for the security, maintenance, and backup of the hardware, software, and data stored in these facilities.

While ICT equipment rental and outsourcing of data processing functions have long been sold by service providers, increased access to broadband Internet and the development of virtualization technologies led to the rapid expansion of cloud computing in the 2000 's. Virtualization allows the functionality of a single piece of hardware equipment to be accessed from other computing resources, each with a dedicated operating system. The related technology of containerization facilitates sharing the functionality of hardware and a single operating system. Cloud computing relies on these technologies to provide customers with a specified quantity of ICT functionality when it is needed, while reducing the amount of ICT equipment that they themselves own and maintain. Amongst the first companies to provide these services was Amazon, which had developed pooled computing resources for internal functions that they then offered to external customers beginning in 2006.

Cloud computing services vary based on the type of ICT resources that are accessed.

Infrastructure as a Service (IaaS) is the provision of access to computing, storage, and/or 
networking resources alone. Platform as a Service (PaaS) is geared towards customers that are developing new software applications where an operating system and development tools are provided in addition to infrastructure. Finally, Software as a Service (SaaS) provides customers access to software applications through the Internet where the software runs on the operating system and computing infrastructure of the cloud services provider.

\section{Prices}

Cloud computing services are primarily priced with subscription and usage fees. Large cloud providers offer numerous service packages with varying price determining characteristics and pricing units, making constant quality service pricing very challenging.

IaaS computing capacity can be provided in three categories, either on-demand, in prereserved increments, or at periods when usage is low. Prices are typically charged per hour, depend on the amount of memory required, with the highest rates for on-demand service and lowest rates for service provided only at off-peak times. In some cases, hourly rates may be assessed in intervals of seconds. Over the last number of years some cloud services providers have moved from per hour charges to per second charges, dramatically changing the price structure. For each of these categories, prices vary based on the operating system used, and the amount of central processing units (CPUs), memory, and intermediate file storage available, among other factors.

IaaS data storage services are usually priced per gigabyte of data stored per month, with lower rates for each subsequent gigabyte of data stored above pre-determined thresholds. Monthly discounts are provided for customers who commit to storing data for longer periods of time. Data transfer services are similarly charged based on the amount of data transferred in and out of the cloud.

PaaS services are typically charged based on the computing capacity and data storage requirements used, as with IaaS. SaaS is typically charged as a subscription fee per user per month, with discounts granted to buyers committing to more users and/or longer service periods. Usage-based charges per user session are assessed less frequently.

In addition to these service-specific variables, prices are also based on the location of the infrastructure that is used. Higher prices are charged to access resources in data centers where demand is higher. While service quality is largely the same regardless of the infrastructure location, customers may prefer to store sensitive information in certain countries based on national privacy laws. Customers may also obtain very small improvements in data latency ${ }^{2}$ from using data centers geographically closer to the resource users.

\footnotetext{
${ }^{2}$ Data latency is the time it takes for data packets to be stored or retrieved.
} 
While payments for cloud computing services are typically assessed in the provider's home country currency by default, some large global providers allow for payments to be made in the currency of the buyer's choice. In these cases, charges are determined based on the seller's offered exchange rates at the time of the transaction.

\section{Cloud Computing-The Industry}

The cloud computing market is growing rapidly. According to industry estimates, the revenue of global public cloud ${ }^{3}$ computing services will increase 17.5 percent in 2019 to US\$214.3 billion (Figure 1). Furthermore, the market revenue is projected to reach $\$ 331.2$ billion in 2022, which is 54.5 percent higher than the 2019 estimate. All segments of cloud computing services ${ }^{4}$ are expected to show double-digit growth rates up to 2022 . SaaS will remain as the largest segment of the market in the next years, retaining its share at around 43 percent. On the other hand, it is estimated that the the fastest-expanding segment will be IaaS, which is forecast to grow an estimated 25.9 percent annually on average, increasing its portion in the cloud computing market from 16.7 percent in 2018 to 23.1 percent in 2020 .

The cloud computing industry is dominated by a small number of very large organizations, such as Amazon (Amazon Web Services, AWS), Alibaba and Microsoft (Azure). For example, according to Gartner, as shown in Figure 2, the top five cloud service providers accounted for nearly 77 percent of the global IaaS market in 2018, up from less than 73 percent in 2017 . The providers continue to solidify their position through economies of scale and aggressive research and development activities. The market forecasts consolidation will occur as organizations and developers look for standardized, broadly supported platforms for developing and hosting cloud applications. ${ }^{5}$

\footnotetext{
${ }^{3}$ Public cloud infra structure is provisioned for use by multiple customers, while private cloud infrastructure is restricted for use by a single customer only.

${ }^{4}$ Cloud services a re usually cla ssified into services rela ted to IT infrastructure (i.e., infra structure-as-a-service, or Ia aS), platform provision (i.e., platform-as-a-service, or Pa aS), a ccess of software (i.e., software-as-a-service, or Sa a S). Ga rtner Research includes a dditional ca tegories for business process automation (i.e., businessprocess-as-a-service, or $\mathrm{BPa}$ aS) a nd cloud provision of management and security tools.

${ }^{5}$ Gartner Research, Press Release 29 July 2019.
} 
Figure 1. Global Cloud Computing Market Forecast

(Billions of U.S. Dollars)

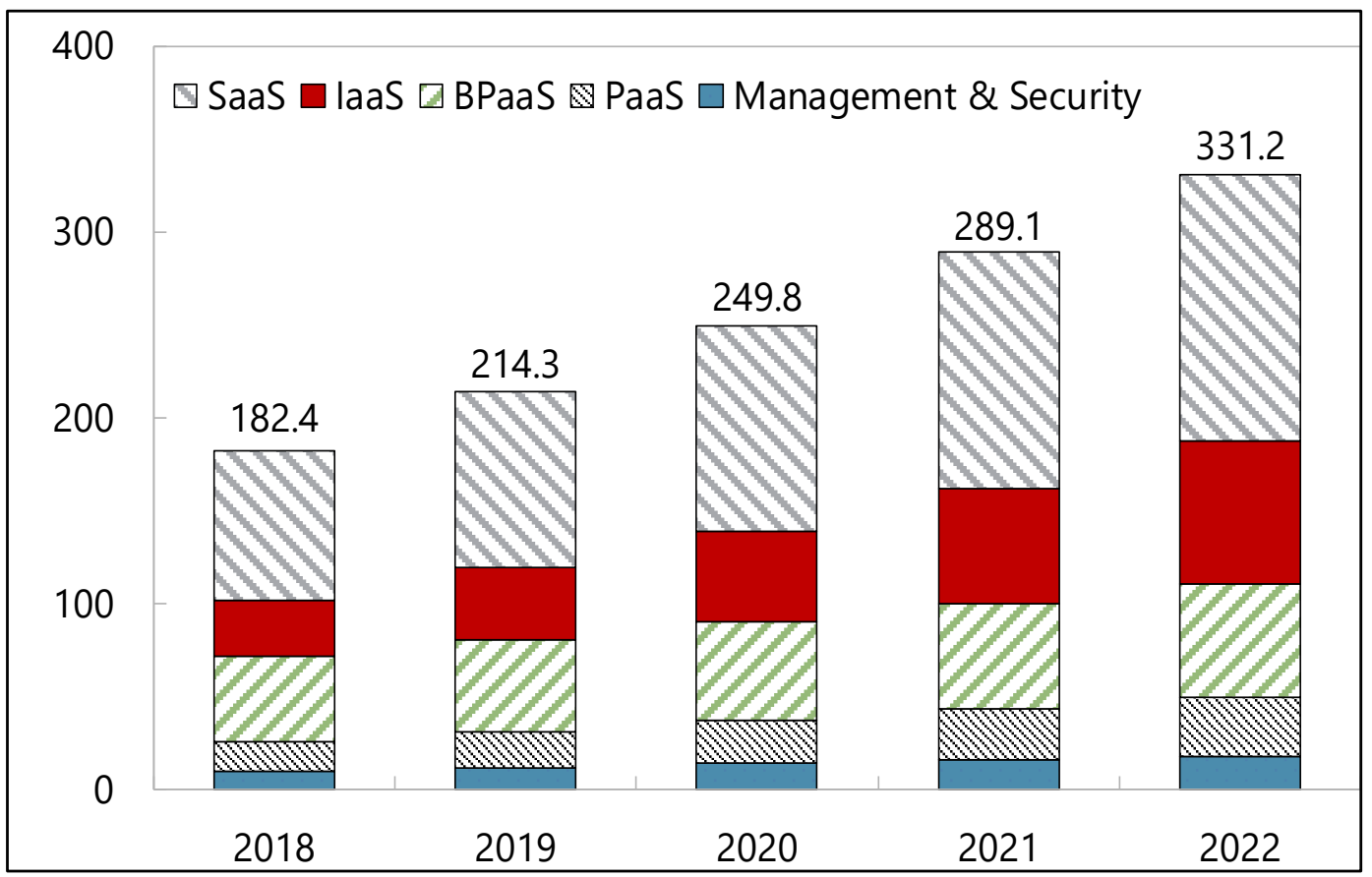

Source: Gartner (April 2019).

Note: Software-as-a-service (SaaS), Infrastructure-as-a-service (laaS), Business-process-as-a-service (BPaaS), Platform-as-a-service (PaaS).

Figure 2. Global laaS Cloud Computing Market Share (Percent)

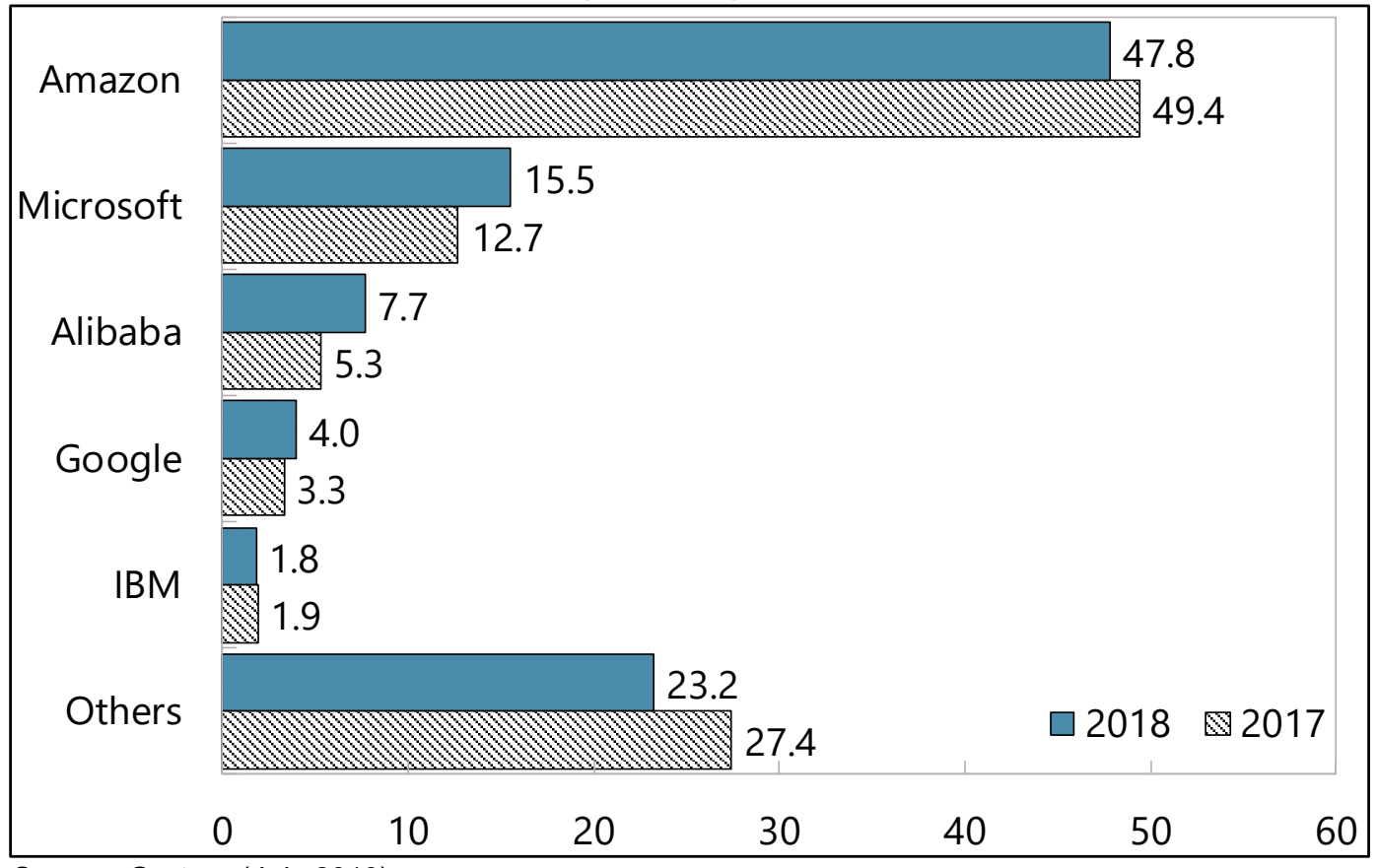

Source: Gartner (July 2019). 
The shift to the cloud can also be observed in the demand-side statistics. In Figure 3, the OECD reports that, on average, the share of businesses in OECD countries that purchased cloud computing services increased nearly 6 percentage points between 2016 and 2018 . Businesses classified in the Information and communication sector and the Professional, Scientific and Technical sector increased their use of the cloud by almost 10 and 8 percentage points respectively within two years. Figures for emerging market and developing economies indicate the rapid expansion of cloud computing services as well. According to the China Academy of Information and Communications Technology, a Chinese government research institute, the public cloud market in China grew 65.2 percent in 2018 and is expected to expand almost threefold by 2022. Also, the public cloud services revenue in India to reach $\$ 2.4$ billion in 2019, an increase of 24.3 percent from $2018 .{ }^{6}$

\section{Figure 3. Share of Businesses Purchasing Cloud Computing Services in OECD Countries, by Industry ${ }^{1}$}

(Percent)

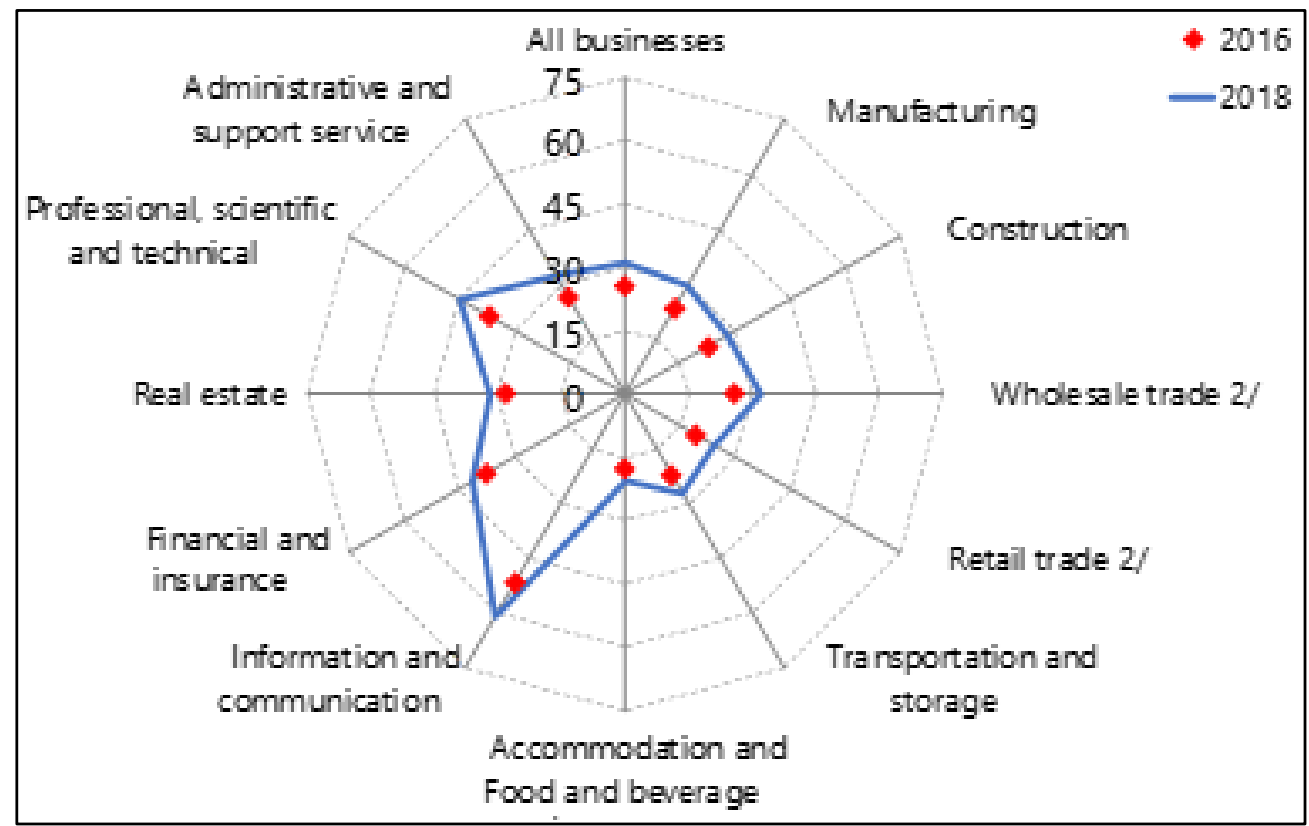

Sources: OECD, ICT Access, and Usage by Business Database.

${ }^{1}$ Based on a simple average of the member countries. The latest figure is used is case these there is not any data for the period. Canada is excluded due to a methodological break in 2017.

${ }^{2}$ Except of motor vehicles and motorcycles.

The extent of cloud adoption differs across countries, sectors, and firm size. Among OECD countries, the share of businesses purchasing cloud computing services (Figure 4) in 2018 ranges from a high of 65 percent in Finland to a low of 10 percent in Latvia. The OECD reports (Figure 3 ) that over 60 percent of firms in the Information and Communication sector use cloud computing services but the comparable figure for Accommodation and Food and Beverage services is only 21 percent. Size also matters as shown in Figure 5, where larger firms are more likely to purchase cloud services than small firms.

\footnotetext{
${ }^{6}$ Gartner Research, Press Release 18 June 2019.
} 
Figure 4. Businesses Purchasing Cloud Computing Services (2018) ${ }^{1}$ (Percent)

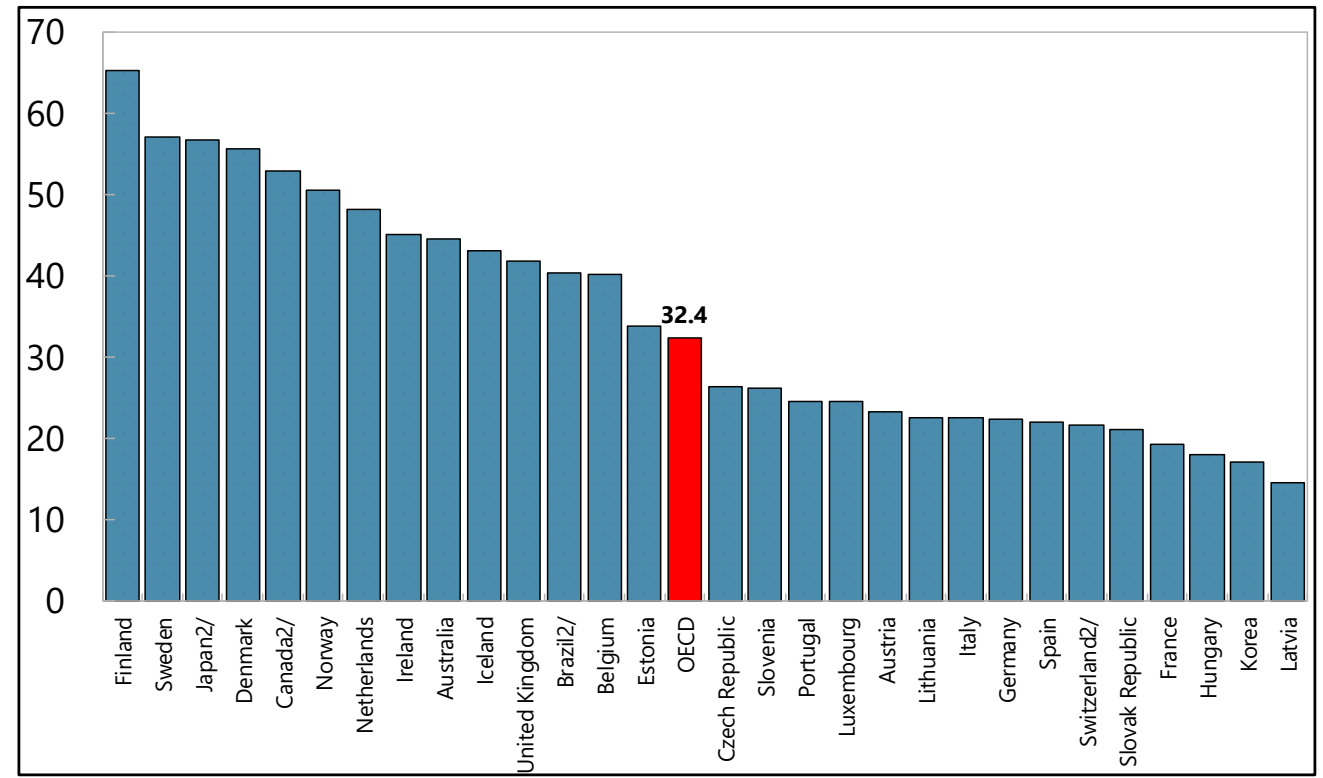

Sources: OECD, "ICT Access and Usage by Business."

${ }^{1}$ The latest figure is used in case there is not any data for 2018.

${ }^{2}$ Difference in methodology.

Figure 5. Share of Businesses Purchasing Cloud Computing Services in OECD Countries, by Business Size ${ }^{1}$

(Percent)

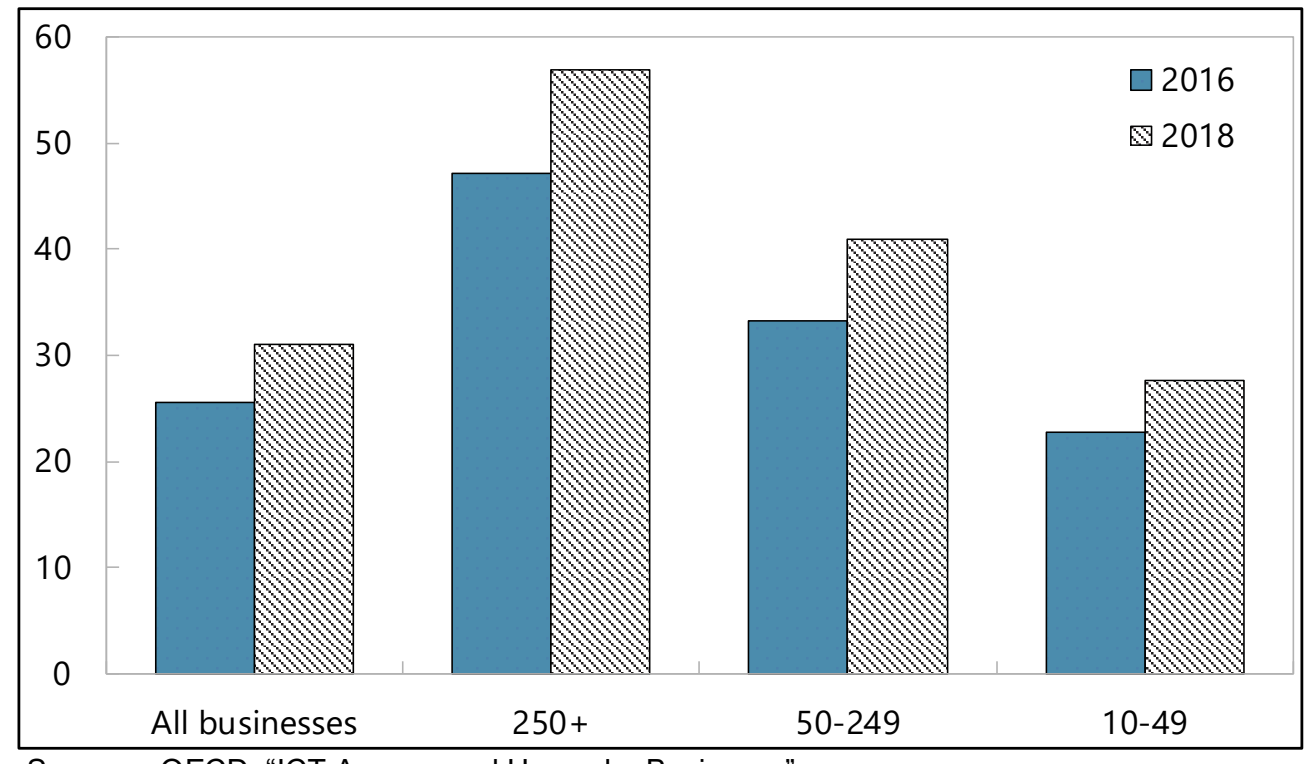

Sources: OECD, "ICT Access and Usage by Business."

${ }^{1}$ Based on a simple average of the member countries. The latest figure is used in case there is no data for the period. Canada is excluded due to a methodological break in 2017. 


\section{The Challenges Cloud Computing Poses for National Accountants}

Cloud computing is posing several challenges for national accountants. The transactions associated with the sale and purchase of cloud-based IT services are quite different from the transactions associated with the more traditional model where firms would self-provision their IT services. One way to illustrate the far-reaching nature of these changes is by way of an example that compares how national accountants record 'traditional' computing services such as infrastructure, storage and networking with how they record 'cloud computing' services in the various economic statements that they compile.

Consider four firms:

- a firm that manufactures and sells IT equipment (e.g., servers);

- an accounting firm that requires a server to run their accounting practice;

- a clothing wholesaler that requires a server to deliver wholesaling services; and

- a computer processing firm that provides cloud computing services such as processing services and storage services.

In the traditional model, where firms internally provision their IT services, the accounting firm and wholesaler would purchase servers from the IT equipment manufacturer/wholesaler, hire staff to maintain their servers and use this capital and labor to supply IT services to the rest of the firm. Table 1 presents a stylized production and generation of income account under this traditional model.

\section{Table 1. Traditional Model}

\begin{tabular}{|l|lcc|}
\hline Transaction & $\begin{array}{l}\text { IT Equipment } \\
\text { Manufacturer }\end{array}$ & $\begin{array}{l}\text { Accounting } \\
\text { Firm }\end{array}$ & Wholesaler \\
\hline Goods and Services Account & & 50,000 & 50,000 \\
Gross Fixed Capital Formation - IT Equipment. & & & \\
Output & 100,000 & & \\
Servers & & 25,000 & \\
Accounting Services & & & 40,000 \\
Wholesaling Services & & & \\
& & 5,000 & 10,000 \\
Intermediate Consumption & 50,000 & 10,000 & 15,000 \\
Inputs related to the provision of internal IT services & & & \\
Other inputs & 50,000 & 10,000 & 15,000 \\
Gross Value Added & & 3,000 & 5,000 \\
Compensation of Employees (IT employees) & 25,000 & 5,000 & 7,000 \\
Compensation of Employees (non-IT employees) & 25,000 & 2,000 & 3,000 \\
\hline Operating Surplus, Gross & \multicolumn{3}{|c}{} \\
\hline
\end{tabular}

In the cloud services model we observe a different set of transactions. In this model the IT services firm purchases servers from the IT equipment manufacturer. The accounting firm and wholesaler no longer record a capital outlay, nor do they need to hire labor to manage 
their servers. Instead, they have a new cloud services expense which records the purchase of cloud services from the IT services firm. The structure of the production and generation of income accounts under the cloud services model is illustrated in table 2.

Table 2. Cloud Model

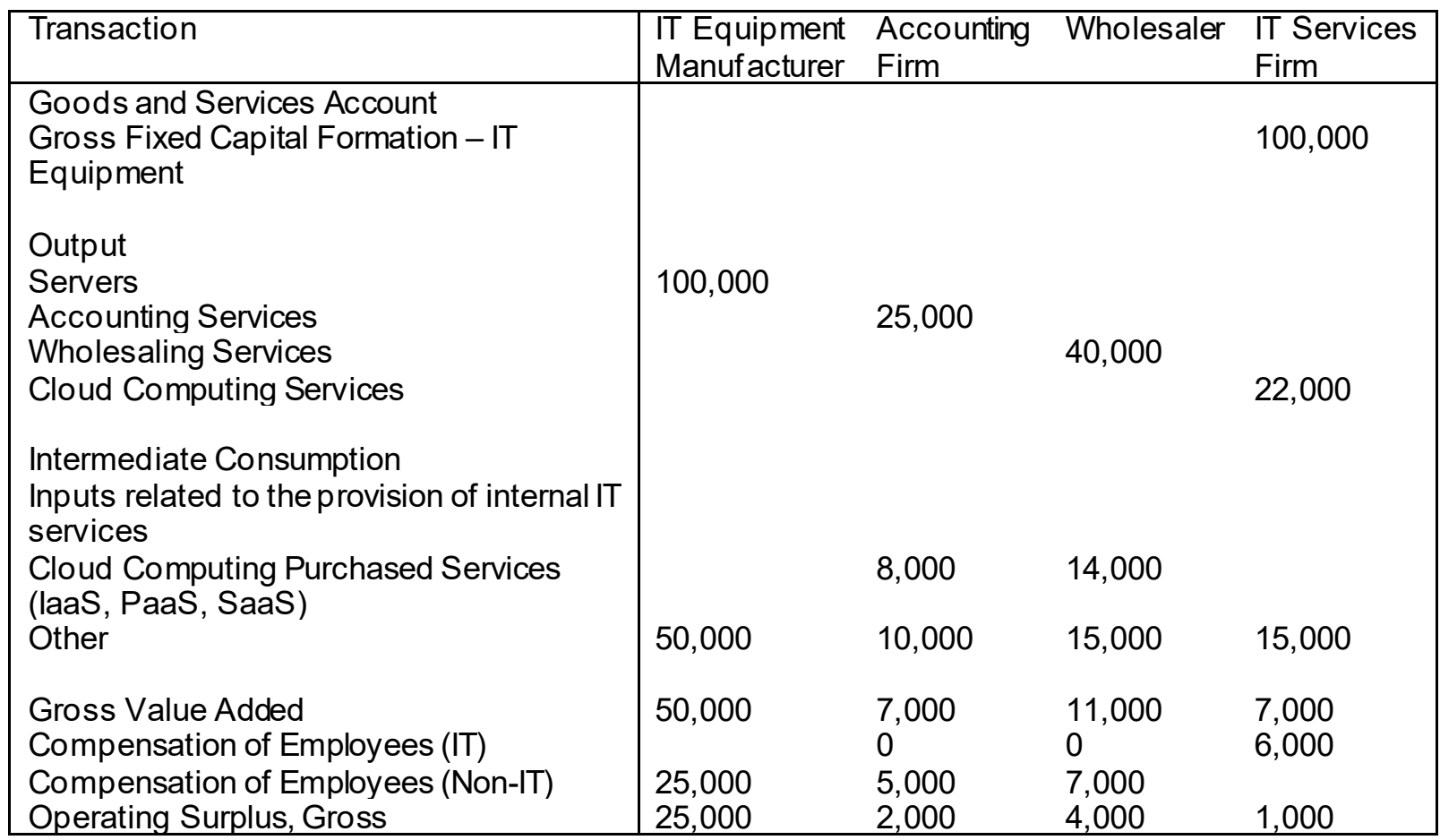

The structure of the production and generation of income accounts have changed with the introduction of the IT services firm and subsequent sale of cloud services. In the traditional model, the accounting firm and wholesaler both established internal IT departments and these departments provided IT services to the rest of the organization. These IT services were not recorded as output by the firm since they represent output produced and consumed by the same firm. ${ }^{7}$ With the introduction of the IT services firm, the IT services are produced outside the firm and sold on the market. Given these services are now sold on the market the national accountant must record the output of IT services in the IT services industry and then show the purchase of these services by the consuming industries.

The result is a new product has been added to both the output and input matrixes and economy wide output and input has increased - i.e., there has been a grossing up of output and inputs by the value of the IT services. ${ }^{8}$ Economy-wide gross value added under these

\footnotetext{
${ }^{7}$ The System of National Accounts 2008 (2008 SNA) defines output a " "goods and services produced by an esta blishment... excluding the value of goods and services consumed by the same establishment, except for goods and services used for capital formation (fixed capitalor changes in inventories) or own final consumption" (paragraph 6.89).

${ }^{8}$ This is not a new phenomenon. The fragmentation of production has led to a nexpansion of output and inputs in other industries a s well.
} 
assumptions remains the same (this is by design at this point - mainly for illustrative purposes). Economy-wide gross operating surplus increases due to efficiency gains.

In addition to changes in total output and intermediate consumption the economy wide investment pattern has shifted. In the traditional model both the accounting firm and wholesaler recorded IT investment. In the cloud services model IT investment is concentrated in the IT services firm. Finally, IT labor services have also shifted from the accounting firm and government department to the IT services firm.

The above example, while illustrative, is simplified and does not fully capture all the possible changes that could occur. As noted earlier, cloud computing has arisen because it is more efficient for firms to purchase computing services then to purchase, operate and maintain IT equipment. In the past, firms would invest heavily in IT equipment and IT capacity, often having to purchase up to their maximum computing capacity needs even though their maximum capacity was only required periodically. Cloud computing allows firms to purchase what they need when they need it, allowing them to scale their operations quickly if demand spikes. In theory, cloud computing should result in an economy wide rationalization of IT services.

This rationalization can be overlaid on the previous example. Assume that the IT services firm only needs to purchase a single server because it has determined that it can meet the needs of both the accounting firm and wholesaler by shifting capacity as required. In addition, it has determined that it only needs to hire half as many employees to maintain the server rather than the full complement of employees required by the accounting firm and wholesaler. These changes are shown in table 3.

Table 3. Cloud Model with Rationalization

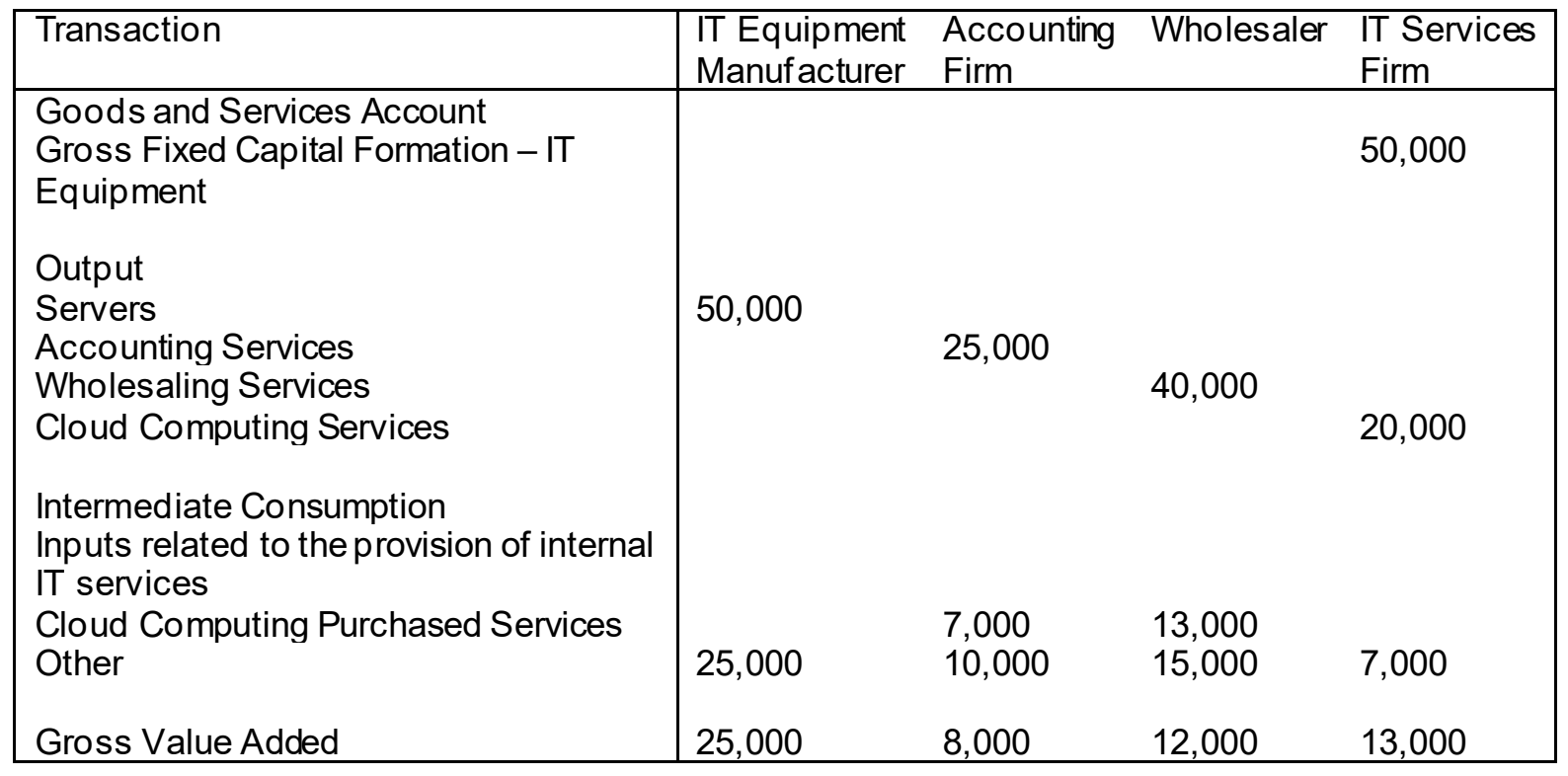




\begin{tabular}{|l|llll|}
\hline Compensation of Employees (IT) & & 0 & 0 & 3,000 \\
Compensation of Employees (Non-IT) & 12,500 & 5,000 & 7,000 & \\
Operating Surplus, Gross & 12,500 & 3,000 & 5,000 & 10,000 \\
\hline
\end{tabular}

In this case, the economy-wide output will decrease since both the output of the manufacturing firm and cloud services firm declined (total output=135,000). Additionally, total economy-wide value added also declines, due mainly to the decline in the production of servers.

The rationalization propagated by the move to the cloud results in a reduction in the output of servers, labor and cloud computing services. The decline in servers and labor is relatively straightforward but the reduction in cloud computing services requires a little more explanation.

In the traditional model both the accounting firm and wholesaler were required to purchase more IT capacity than they required since they had to purchase up to their maximum requirements rather than their average requirements. Because the IT service provider can leverage capacity across firms they only need to purchase the average capacity of each firm. This results in a lower measured output of overall computing services when moving to the cloud model because the excess capacity is no longer required. The accounting firms and wholesaler are now only purchasing their average requirements and their gross value added should increase due to this rationalization.

Productivity in the accounting firm, wholesaler and IT services firm should increase as computing resources are centralized. Over the longer run, increases should be seen in both labor productivity and multi-factor productivity since the same output will be produced with less labor (IT staff) and less capital (excess capacity is no longer required). These productivity gains should be most notable in those industries where there is considerable movement from traditional ICT investment to the use of cloud services.

Another possible and important change involves the geographic provision of the cloud services. In the traditional model, the server would be located at the same physical premises as the other factors of production. Under the cloud model it is quite possible for the cloud provider to be in one economic territory and the cloud purchaser to be in another economic territory. This means that the purchase of the cloud services could represent an import rather than a domestic purchase.

The fact that these services can be provided by firms located in another economic territory further changes the picture. Incorporating the notion that the IT service provider is outside the economic territory means additional import and export transactions need to be recorded. These changes are illustrated in Table 4.

Table 4. Cloud Model with Rationalization and Foreign Provision 


\begin{tabular}{|c|c|c|c|c|}
\hline \multirow[b]{2}{*}{ Transaction } & \multicolumn{3}{|c|}{ Economic Territory A } & \multirow{2}{*}{$\begin{array}{c}\text { Economic Territory B } \\
\text { IT Services Firm }\end{array}$} \\
\hline & $\begin{array}{c}\text { IT } \\
\text { Equipment } \\
\text { Manufacturer }\end{array}$ & $\begin{array}{l}\text { Accounting } \\
\text { Firm }\end{array}$ & Wholesaler & \\
\hline $\begin{array}{l}\text { Goods and Services Account } \\
\text { Exports of Servers } \\
\text { Exports of Cloud Services } \\
\text { Imports of Cloud Services } \\
\text { Gross Fixed Capital Formation } \\
\text { - IT Equipment / Input of IT } \\
\text { Equipment }\end{array}$ & 50.000 & 7,000 & 13,000 & $\begin{array}{l}20,000 \\
50,000\end{array}$ \\
\hline $\begin{array}{l}\text { Output } \\
\text { Servers } \\
\text { Accounting Services } \\
\text { Wholesaling Services } \\
\text { Cloud Computing Services }\end{array}$ & 50,000 & 25,000 & 40,000 & 20,000 \\
\hline $\begin{array}{l}\text { Intermediate Consumption } \\
\text { Inputs related to the provision of } \\
\text { internal IT services } \\
\text { Cloud Computing Purchased } \\
\text { Services }\end{array}$ & & 7,000 & 13,000 & \\
\hline Other & 25,000 & 10,000 & 15,000 & 7,000 \\
\hline $\begin{array}{l}\text { Gross Value Added } \\
\text { Compensation of Employees } \\
\text { (IT) }\end{array}$ & 25,000 & $\begin{array}{l}8,000 \\
0\end{array}$ & $\begin{array}{l}12,000 \\
0\end{array}$ & $\begin{array}{l}13,000 \\
3,000\end{array}$ \\
\hline $\begin{array}{l}\text { Compensation of Employees } \\
\text { (Non-IT) }\end{array}$ & 12,500 & 5,000 & 7,000 & \\
\hline Operating Surplus, Gross & 12,500 & 3,000 & 5,000 & 10,000 \\
\hline
\end{tabular}

Under this scenario economy-wide output declines in territory A since the cloud services (and the associated output) are provided by a foreign firm in territory B. Intermediate consumption remains the same since the accounting firm and wholesaler continue to purchase cloud computing services. The only difference is these services are now provided by a foreign entity and recorded as an import.

As noted in the first section of this paper, the provision of cloud services is concentrated in a small number of large firms. For these firms to be able to deliver service to their clients they have established business operations and data centers in various locations across the globe.

Expanding the example from earlier a third territory $(\mathrm{C})$ is added. Territory $\mathrm{C}$ contains a data center controlled by the cloud computing firm headquartered in territory B. The cloud computing firm also maintains a data center in territory B. The accounting firm and wholesaler located in territory A continue to purchase cloud computing services from the firm in territory $\mathrm{B}$. The firm in territory $\mathrm{B}$ is free to move production form $\mathrm{B}$ to $\mathrm{C}$ to deliver the cloud computing services to the firm in territory A. 
Table 5. Cloud Model with Rationalization and Foreign Provision with Multiple Data Centers

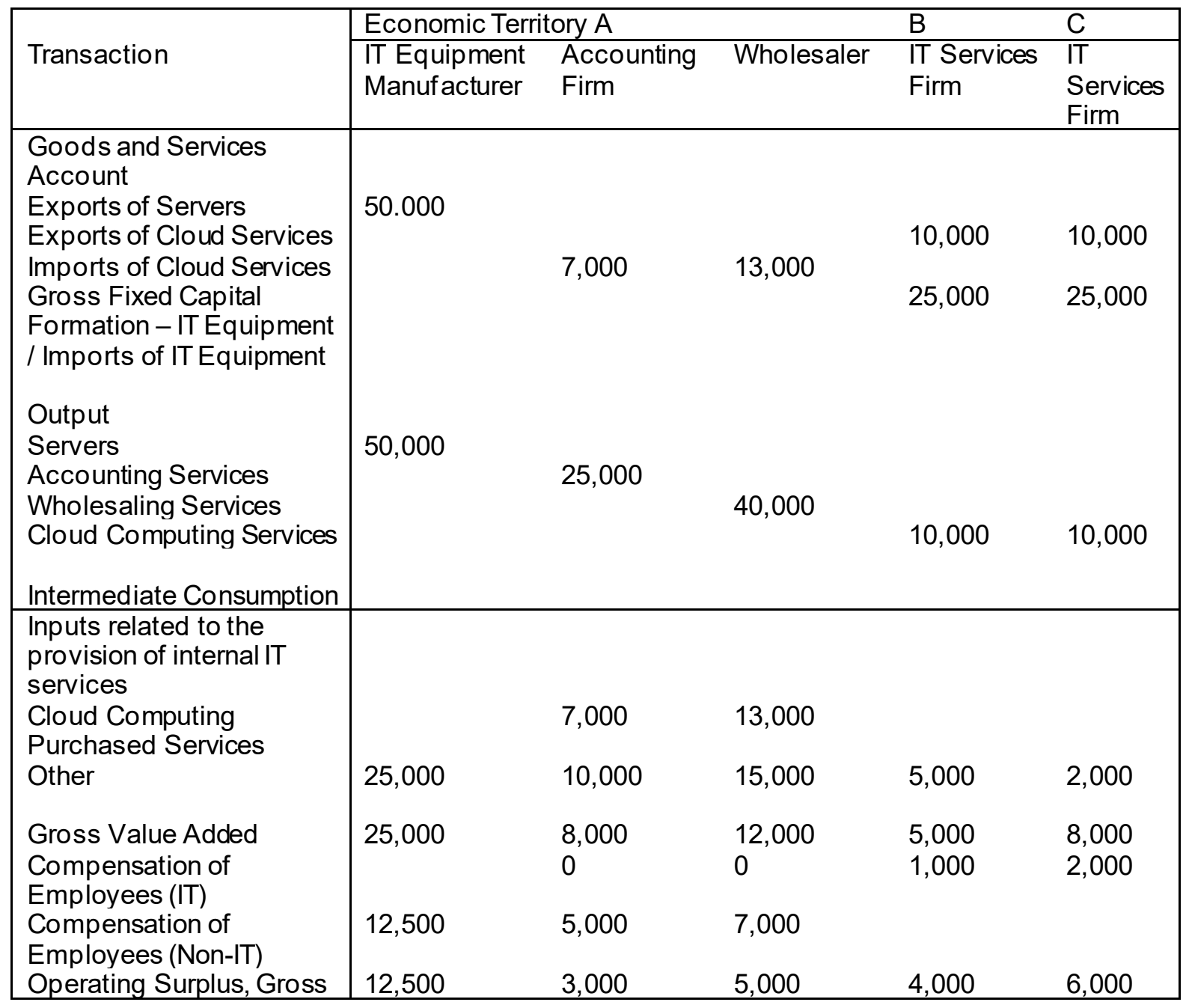

The question facing the national accountant is whether the accounting firm and wholesaler are importing from $\mathrm{B}$ or $\mathrm{B}$ and $\mathrm{C}$. If their direct payment is going to $\mathrm{B}$, then the import is from $B$ even if $B$ subsequently imports from $C$. Once this is determined the compiler is still left with the question 'how much' since during any given accounting period A could receive all their services from $\mathrm{B}$ or all their services from $\mathrm{C}$ or a combination thereof.

The Sixth Edition of the IMF's Balance of Payments and International Investment Position Manual (BPM6) details measurement of trade on an ownership basis, rather than a physical basis. If the consumer of cloud services located in country A is billed by an establishment in country B that manages the delivery of the services, the source of the imports of services is country $\mathrm{B}$. That establishment may have a contract with a data center in country $\mathrm{C}$ where the actual computing takes places, and payments under that contract would be an import by 
country B from country C. Compiling these service flows in the proper economic territorites is another challenge facing national accountants and balance-of-payments statisticians.

The final measurement challenge facing national accountants concerns their ability to develop volume estimates to have an accurate measure of real growth. Cloud computing services are transacted between firms, and therefore cloud computing introduces the need for new service price indexes. In the past, when firms purchased their own equipment these investment goods would be deflated using 'goods' prices which tended to be readily available. While ICT goods prices are a challenge, they are less of a challenge than the production of reliable service price indexes. In addition to the difficulty in collecting and compiling service prices, price statisticians and national accountants also face challenges associated with the fact that these services are often bundled and sold on contract with a wide range of discounts and incentives. Papers presented at the 2018 meeting of the Voorburg Group on Services Statistics show the approaches that national statistical offices in Finland, Poland, Israel, and the United States have taken in developing producer price index es that include the provision of cloud computing services. ${ }^{9}$

The above example illustrates the significant structural changes a large-scale shift by firms towards the adoption of a cloud strategy for the provision of IT services has on an economy. All things equal, if a large share of firms begin to purchase a large share of their IT services users of national account data can expect (all things equal):

- a softening in output and investment in IT equipment;

- investment in IT equipment to become increasingly industrially and geographically concentrated;

- increases in the cross-border flow of commercial services;

- increases in the relative size of IT services industries;

- increased concentration of IT related labor in those industries providing cloud services;

- potential gains in productivity due to the rationalization associated with cloud computing;

- appearances of new products and processes made possible by cloud computing; and

- change in the geographic concentration of imports of ICT equipment.

\section{Updating Our Toolbox to Account For The Cloud}

It is apparent that the wide-scale move to cloud computing will have a significant impact on the interpretation of macroeconomic statistics. As can be seen from the previous examples, the current macroeconomic frameworks can properly capture and record this activity and present it to users in a meaningful way. While the framework appears to be sufficient, the more significant challenges facing national accountants relates to the statistical infrastructure

\footnotetext{
${ }^{9}$ Links to the papers by Tag, et al (Finland), Cebula, et al (Poland), Tal (Israel), and Baer, et al. (U.S.) a re provided in the references.
} 
in place at most statistical offices to properly capture this activity. In most NSOs, the existing statistical infrastructure is more suited for the traditional IT service delivery model described above. It is less suited for the emerging cloud model use to deliver IT services. To properly account for cloud computing, there are three areas where NSOs may want to invest to ensure their national accounts are "cloud" ready. First, NSOs and International Organizations (IOs) will need to invest in updating classification systems to ensure cloud computing services are property identified in national accounts. Second, NSOs and IOs will need to develop new data sources to ensure the activity is properly captured. Third, NSOs and IOs may need to consider conceptual changes to their frameworks, specifically as it relates to cross border flows and the recording of investment in software.

\section{UPDATING ClASSIFICATION SYSTEMS}

Classification systems are critical building blocks that support the reporting and presentation of economic data. There are many classification systems that support statistical systems such as geographic classification systems, institutional sector classification systems, occupational classification systems, product classification systems and industry classification system. The classification systems most impacted by the advent of cloud computing are the product classification system and the industrial classification system.

A product classification system classifies goods and services that are the result of production in the economy. The classification system groups the millions of goods and services in homogenous groups or classes to help data users better interpret the goods and services that are being produced, used and consumed in an economy.

An industrial classification system classifies the producers of goods and services that are the result of production in the economy into distinguishable groups or classes. The producers are assigned to groups or classes based on the similarity in their production function and the goods and services they produce.

The phrases "cloud computing," "IaaS," "PaaS," and "SaaS" do not appear in either Central Product Classification (CPC) Version 2.1 or International Standard Industrial Classification of All Economic Activities (ISIC) Version 4. As a result, it is not clear that statistical agencies are classifying these services consistently in production statistics and associated deflators. With the large and growing sales of cloud computing, future updates to product classifications should provide clear guidance on these services individually. Strong interest in data about cloud computing services calls for new product and industrial categories dedicated to these services alone.

Presentations at the 2018 meeting of the Voorburg Group on Services Statistics highlighted some inconsistencies in the classification of cloud computing products. While there was general agreement that IaaS is classified in CPC subclass 83159, Other hosting and IT infrastructure provisioning services, the treatment of PaaS and SaaS varied. 
The 2018 report of the Eurostat Task Force on Price and Volume Measures for Services Activities report stated that PaaS "is most likely" classified in CPC class 8314, Information technology (IT) design and development. For the U.S., however, this service is classified in a category that concords with CPC subclass 83159 , Other hosting and IT infrastructure provisioning services.

The Eurostat Task Force report states that SaaS should be classified with software publishing, which would place it in CPC subclass 84392, Online software. In the U.S., however, a distinction is made based on whether the provider holds copyright to the software that is provisioned. If they do own the rights, then providing the software through the Internet is classified with software publishing. If they do not own the rights then the service is classified as CPC subclass 83152, Application service provisioning (ASP), defined as the provision of leased software from a centralized, hosted, and managed computing environment.

As cloud computing services have grown, large providers are increasingly offering service bundles. These bundles allow clients to use IaaS for applications that they prefer to manage themselves, PaaS for application that they prefer to design themselves, and SaaS for thirdparty applications that they prefer to access only as needed. While Microsoft has always bundled hosted infrastructure with their original software products, infrastructure-focused service providers have also recently developed software applications that they are offering to customers through a SaaS model. This includes business intelligence tools, such as Amazon QuickSight and Google Cloud DataLab. Within the SaaS category, large service providers are similarly offering a mix of their own developed software solutions and those developed by other publishers. These bundles create additional challenges in consistent product classification.

While most cloud computing services are sold to business and institutional buyers, cloud data storage services and some SaaS products are also sold for personal consumption expenditure. Cloud storage services are included in the Classification of Individual Consumption According to Purpose (COICOP) class 08.3.3, Internet access provision and net storage services. SaaS is classified in COICOP subclass 08.3.9.2, Subscription to audio-visual content, streaming services and rentals of audio-visual content.

As can be seen, cloud computing is combined with other types of products making it difficult for users to understand the transformative shift that may be occurring.

For industrial classification, cloud computing providers are currently recorded in ISIC industry 6311, Data processing, hosting, and related services, along with a variety of services such as data entry and time-share provision of mainframe computers. 
Again, because the classification systems were developed prior to the widescale adoption of cloud computing it is not possible for most NSOs to answer questions such as the size and growth of the cloud computing industry. In order to address these issues it is important for the international community to develop an agreed upon set of product and industrial classes that will facilitate both the collection, presentation and analysis of the data.

Since cloud computing activities have effectively replaced most of the data entry and mainframe-related services, ISIC 6311 could be re-named to Cloud Computing Services. Products within the activity could include IaaS, PaaS, and SaaS, except where the provider holds copyright. Cloud provision of software to which the provider holds copyright could remain classified in the software publishing industry.

The Extended Balance of Payments Services (EBOPS) classification system is used to record and present international imports and exports of trade in services. Imports and exports of cloud services would be considered part of the telecommunication, computer and

information services category. This category is broken down into 7 classes and sub-classes (such as telecommunication services, software services, new agency services. It is not clear whether cloud services would be recorded in the other information services category or the other computer services category. To increase the usability of the classification system and quality of the resulting data it would be useful to update the system to include classes related to the different type of cloud products.

Another important piece of statistical infrastructure that an NSO will need to update is their business register. As new cloud computing firms emerge, these enterprises will need to be added to the business register and coded to the appropriate industries so that they form part of the overall universe of enterprise and institutional units in a given country.

The difficulty NSOs will face when updating their business register concerns how to properly classify the different units within the enterprise. For example, in many cases the service provider is a very large multinational organization with affiliates operating in many different countries. The NSOs will need to determine the exact nature of the operations of the affiliate. Is the affiliate simply a sales office or is the affiliate delivering the cloud service to local and foreign customers? Is the affiliate engaged in research and development activities, producing important intellectual property that benefits the entire multinational organization? The determination of these questions is important because it helps define the types of transaction occurring in the economy.

\section{New Data Sources}

Probably the largest cloud computing measurement challenge NSOs are facing is the need to update its source data collection systems to capture cloud computing activity. Most NSOs use the classification systems noted above as the starting point to design their collection instruments. As these new product classes and industries are developed the questionnaires, 
administrative data processing systems, methods, computational systems need to be updated to reflect cloud computing activity.

One way to present these changes is by identifying the type of information that needs to be collected or acquired, identify possible collection vehicles that may need to be updated or acquired and then make note of any changes that need to be made to these traditional vehicles to ensure the NSO can capture the activity. This is summarized in the following table.

Table 6. Data Needed to Measure Cloud Computing

\begin{tabular}{|c|c|c|}
\hline $\begin{array}{l}\text { Data to be } \\
\text { Acquired }\end{array}$ & $\begin{array}{l}\text { Possible Collection } \\
\text { Vehicles }\end{array}$ & Required Update \\
\hline $\begin{array}{l}\text { Purchases of IT } \\
\text { processing } \\
\text { services }\end{array}$ & $\begin{array}{l}\text { Business Surveys } \\
\text { and Administrative } \\
\text { Tax Forms }\end{array}$ & $\begin{array}{l}\text { In most cases, countries are only collecting information } \\
\text { related to the the purchase of IT consulting firms. Fee } \\
\text { countries are explicitly collecting purchased service } \\
\text { expenditures related to the provision of cloud } \\
\text { computing services such as software subscriptions, } \\
\text { processing time and storage space. }\end{array}$ \\
\hline $\begin{array}{l}\text { Purchases of IT } \\
\text { processing } \\
\text { equipment }\end{array}$ & $\begin{array}{l}\text { Business Surveys, } \\
\text { Administrative Tax } \\
\text { Forms and Customs } \\
\text { Forms }\end{array}$ & $\begin{array}{l}\text { There is no change needed with respect to the } \\
\text { collection of data related to the purchase of IT } \\
\text { equipment. It is possible that NSOs will start to see a } \\
\text { greater consolidation of activity amount a smaller } \\
\text { number of firms. }\end{array}$ \\
\hline $\begin{array}{l}\text { Purchases of } \\
\text { Software }\end{array}$ & $\begin{array}{l}\text { Business Surveys, } \\
\text { Administrative Tax } \\
\text { Forms and Customs } \\
\text { Forms, Own-account } \\
\text { estimation methods }\end{array}$ & $\begin{array}{l}\text { A decision needs to be made regarding the difference } \\
\text { between the purchase of software (which is capitalized) } \\
\text { and a sub scription to software services. If it is deemed } \\
\text { that a software subscription is a purchased service that } \\
\text { is not capitalized it will have a significant impact on } \\
\text { how software is recorded in macroeconomic accounts. }\end{array}$ \\
\hline $\begin{array}{l}\text { Prices of cloud } \\
\text { services }\end{array}$ & $\begin{array}{l}\text { Producer Price } \\
\text { Reports, Consumer } \\
\text { Price Reports }\end{array}$ & $\begin{array}{l}\text { New prices indexes will need to be developed to record } \\
\text { the provision of cloud services to both producers and } \\
\text { consumers. Given the nature of the services and the } \\
\text { rapid technological change, some form of hedonic } \\
\text { measurement is probably required to ensure only pure } \\
\text { price change is recorded. }\end{array}$ \\
\hline $\begin{array}{l}\text { Trade in cloud } \\
\text { services }\end{array}$ & $\begin{array}{l}\text { International Trade in } \\
\text { Services Surveys }\end{array}$ & $\begin{array}{l}\text { Surveys should be expanded to include detailed } \\
\text { questions on imports and exports of cloud services. } \\
\text { These data would help clarify residence of service } \\
\text { providers in complex global cloud service supply } \\
\text { chains where intellectual property assets, IT } \\
\text { processing equipment, and customers are all in } \\
\text { multiple locations. }\end{array}$ \\
\hline
\end{tabular}


To better illustrate the type of changes required, consider the latest annual manufacturing business survey issued by the U.S. Census Bureau, Statistics Canada and the Office of National Statistics in the U.K. as presented in figures 1, 2, and 3.

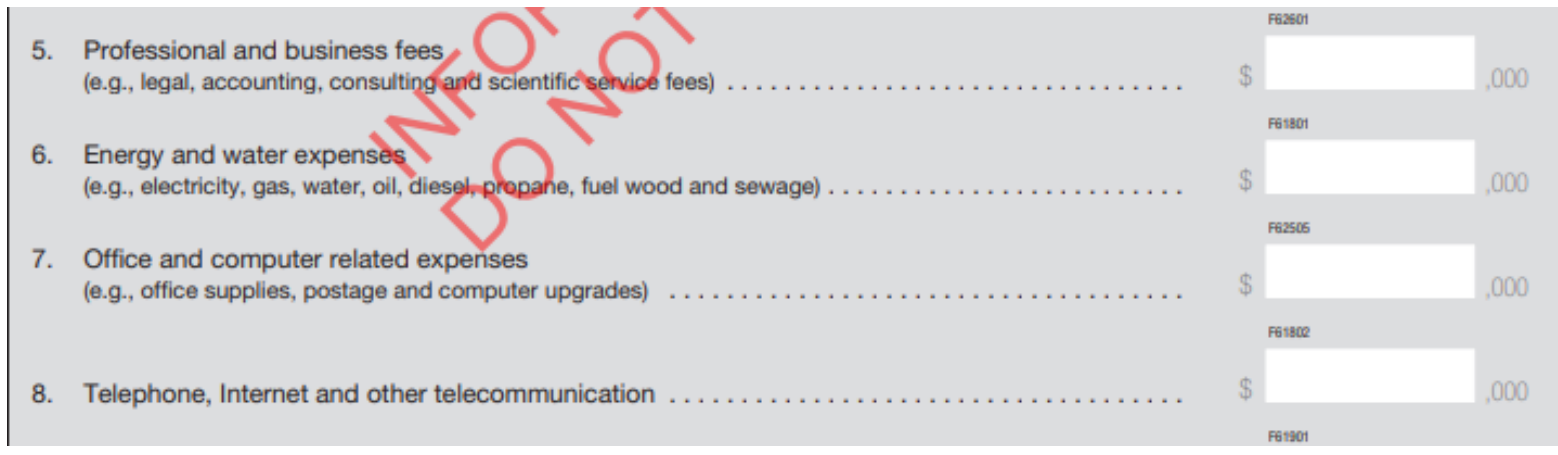

In the case of Canada, cloud computing services could get classified into one of three expense categories: Professional and business fees, office and computer related expenses and telephone, internet and other telecommunication expenses. The questions posed to respondents are shown below.

In reviewing the reporting guide for the questionnaire there is no specific mention of cloud services. Respondents are instructed to include data processing services fees under professional and business fees and data processing expense (equipment, software and software licenses) under office and computer related expenses. Whereas under the telecommunication services question respondents are instructed to include such items as internet service charges, online information provision services, and online access services. Given these instructions it is not clear where to record cloud related storage, processing and software services. Even if the expenses were properly classified, it would be difficult to isolate the economic impact associated with a large scale move to cloud computing.

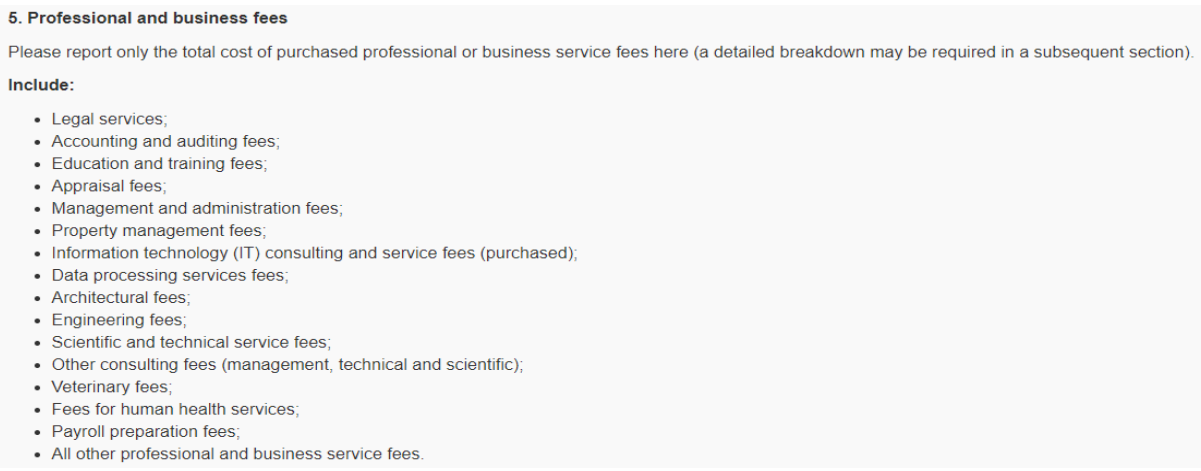




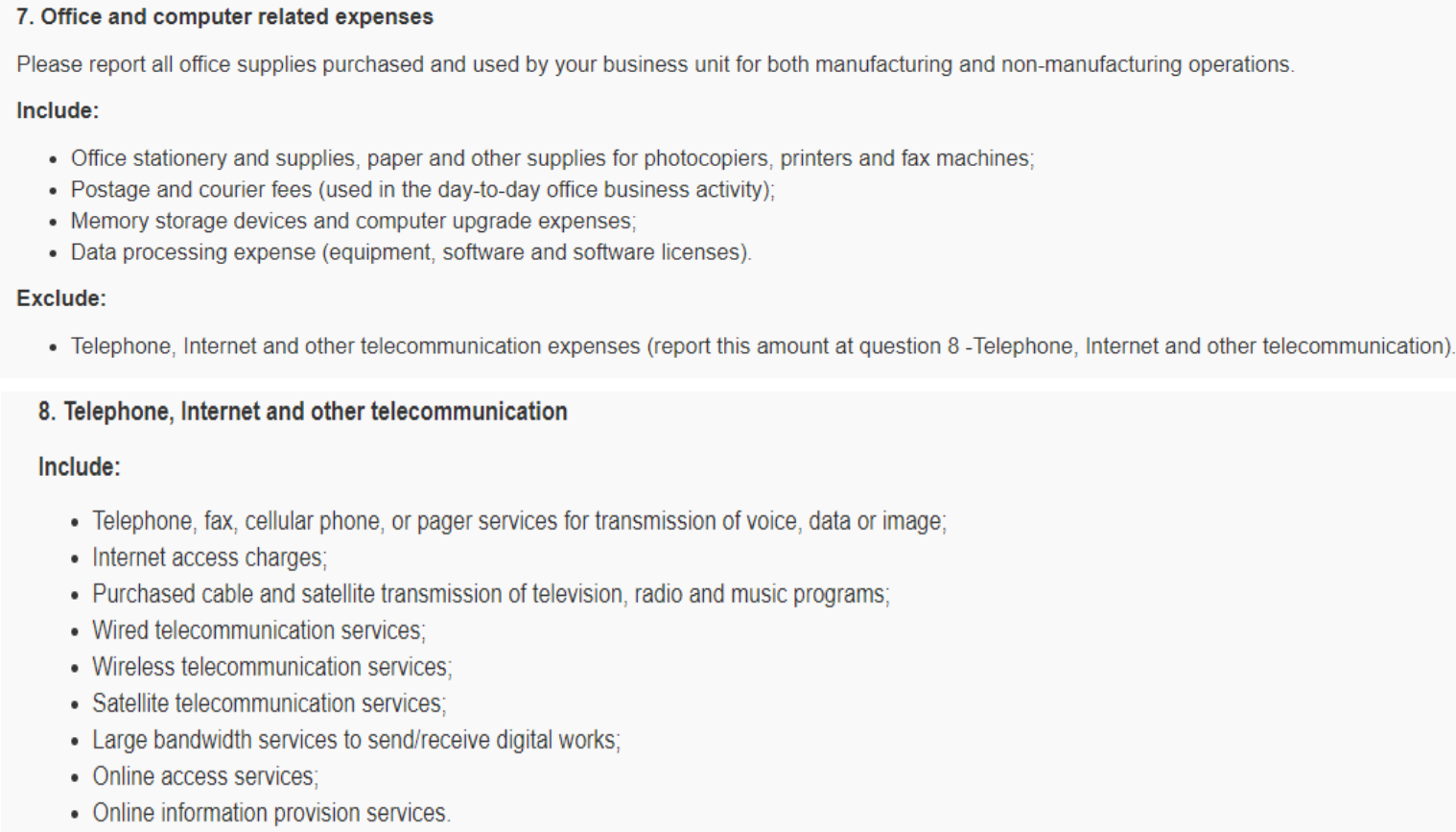

Canada is not alone in its challenge to better articulate and isolate the impact of cloud computing on the economy. A similar situation exists in the U.S., where businesses are asked to report expenses for a broad category labeled "Data processing and other purchased computer services." This includes all "computer-related advice and services." Respondents are not instructed on how to classify cloud computing expenses.

Since distinct classification categories for cloud computing services do not currently exist, it is difficult to find official price statistics that show recent price developments. While NSOs have made progress in collecting prices for emerging cloud computing services, this data is frequently hidden within product categories that include other tangentially related services and are not labeled as cloud computing. New official price indexes dedicated to measuring cloud computing prices are needed to identify these price developments.

3. Expensed Purchased Services - Continued

b. Data processing and other purchased computer services - Include web hosting, computer facilities management services, computer input preparation, data storage, computer time rental, optical scanning services, and other computerrelated advice and services, including training. Exclude expensed integrated systems, repair and maintenance of computer equipment, payroll processing and credit card transaction fees, and expenses for telecommunication services (e.g., Internet, connectivity, telephone) 
The Bank of Japan produces a price index for Entrusted computing services (cloud applications), which has steadily declined since 2010 . This product category closely aligns with SaaS.

\section{Figure 6. Services Producer Price Index for Entrusted Computing Services (Cloud Applications)}

Bank of Japan, 2015=100

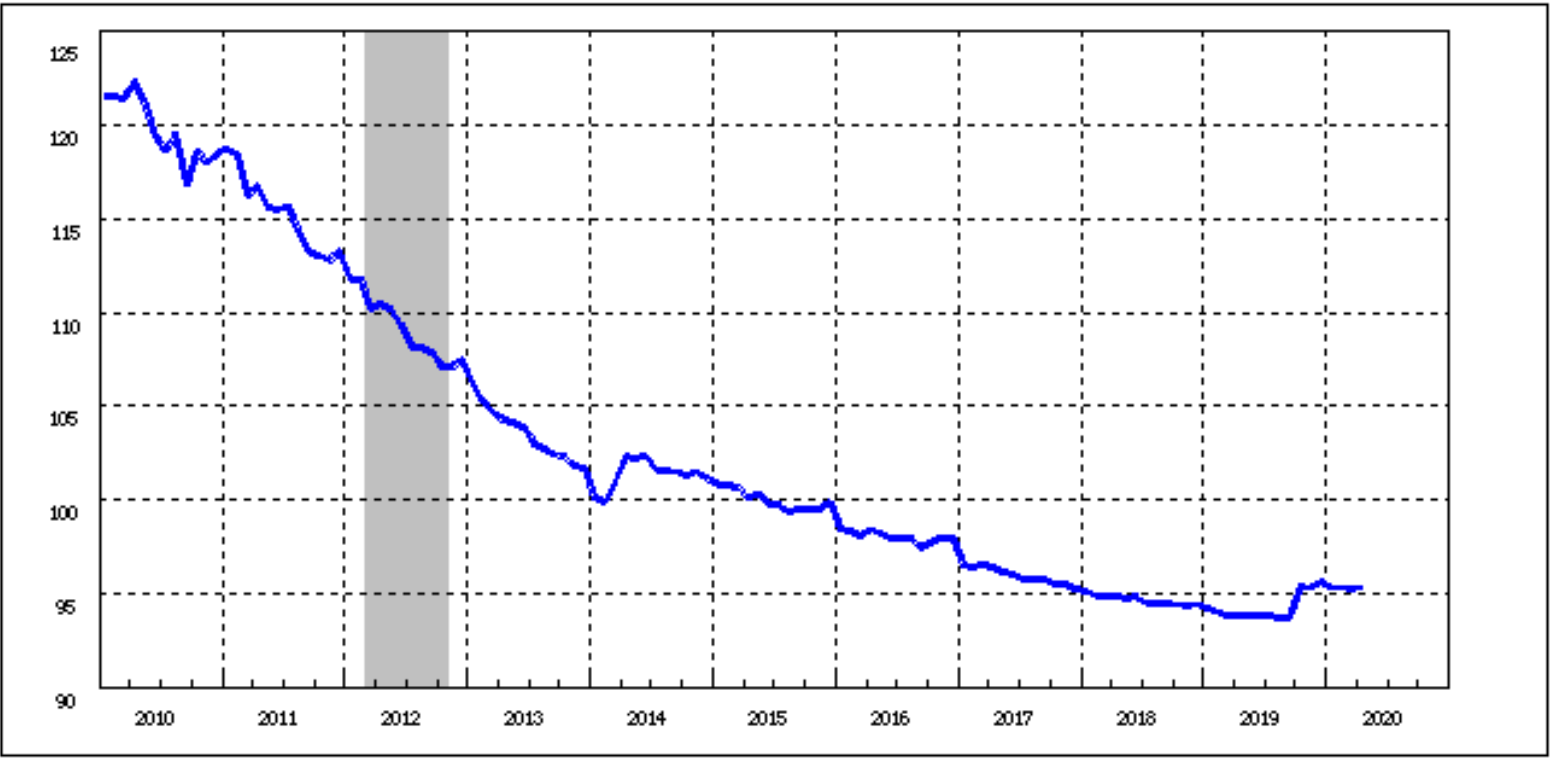

While official price statistics for IaaS services alone are not available, recent research studies have produced interesting results. Byrne, Corrado, and Sichel (2018) constructed price indexes for some of the most important Amazon Web Services (AWS) IaaS products in the U.S. and recorded quality-adjusted price declines of approximately 50 percent between 2009 and 2016. Coyle and Nguyen (2019) evaluated similar products from AWS offered in the U.K and found even larger price decreases over this period. However, the U.S. Producer Price Index (PPI) for the service category that most closely aligns with these services (Hosting, ASP, and other IT provisioning services) was little changed over the same period. 
Figure 7. Official U.S. PPI for Cloud-Related Activities and Byrne, Corrado, Sichel Indexes for Selected AWS Products

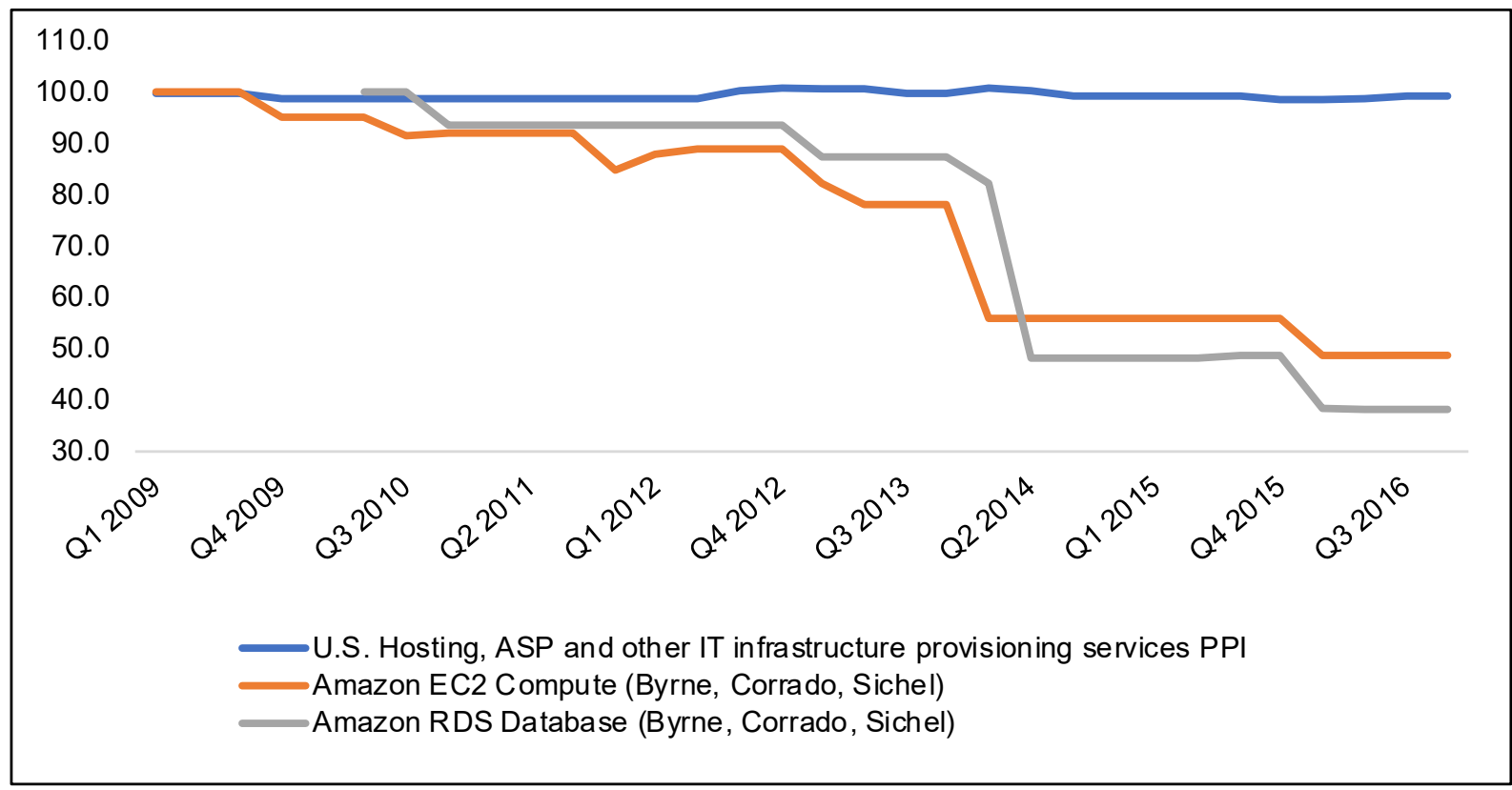

\section{SAMPLE SizeS ANd COVERAGE}

NSOs will additionally need to look at how they design their samples in the face of a widescale adoption of cloud computing services. For example, when statisticians design imports and exports of commercial services questionnaires they generally stratify their surveys to include those firms likely to import or export services such as accounting services, legal services, engineering services etc. The number of firms in an economy importing or exporting these types of services has traditionally been limited to larger, more mature firms. In a world where cloud computing is the primary option for the purchase of IT services the range of firms that should now be considered an importer is increasing and includes smaller firms in less traditional importing industries. Without an expansion of a country's sample of importers, there could be a drift in import statistics due to a growing under coverage in imports of cloud services.

Design strategies and samples sizes should therefore be examined across a host of surveys and statistical programs including:

- Imports of Commercial Services Surveys

- Exports of Commercial Services Surveys

- Surveys related to computer design services

- Price report surveys

- Annual and quarterly business statistics surveys for cloud activities

- Business expense surveys 


\section{Conceptual Challenges}

While most of the challenges related to measuring cloud computing can be addressed by the current suite of measurement frameworks there are a few conceptual challenges that have arisen related to the subscription of software and the location of data centers.

When a firm purchases software such as Microsoft Office, SAP, SAS - whether it is a license or outright purchase of a copy, the SNA recommends that the software be capitalized as a fixed asset and depreciated over time provided it is used continuously in production for more than one year. The SNA goes on to say that if an institutional unit acquires a license to use software and the license is "purchased with a single payment for use over a multiyear period," 10 it should be recorded as an asset. If, on the other hand the acquisition of the copy with a license to use is paid for using a regular (monthly, quarterly) stream of payments it should be recorded as payments for service since there is no indication that the firm requires the service for more than one year.

The pay as you go nature of cloud computing poses some guidance questions that need to be addressed. Consider the following scenarios:

a. A firm sets up an account with a cloud provider by which its employees can use a specific software on an as needed basis for the next two years. The firm is billed according to its usage.

b. A firm subscribes to a cloud provisioned software service on a month to month basis. It has been doing this for the last three years.

c. A firm subscribes to a cloud provisioned software service for a baseline of 20 users and enters into a three-year contract. The contract states that additional users can use the software and that the firm will be billed monthly for this additional usage.

In each of the above scenarios it is unclear how these transactions should be classified. In the first two scenarios it is unclear whether the purchase should be recorded as an asset or intermediate expense. In the third case it is unclear as to the value of the asset. Given the changing and dynamic pricing models associated with cloud computing there are many more scenarios that could be illustrated. It is not realistic to think that treatment should be determined on a case by case basis. Guidance and recommendations are required to identify when the cloud services should be treated as an asset or as intermediate consumption.

A second conceptual challenge facing statisticians concerns the geographic location of the 'production' of cloud services. From a statistical compiler's perspective when all the family photos are stored on the family laptop the calculations are straight forward. When it is decided to upload all the family photos to the cloud and pay a monthly storage fee it gets a little more complicated. Microsoft has a nice feature on its website where it informs its

${ }^{10}$ SNA 10.100. 
clients where it stores their data. The figure below lists where customer data for Asia countries is stored. As you can see, the data are stored in a variety of locations and the location differs depending on the platform.

Afghanistan, Bangladesh, Bhutan, Brunei, Cambodia, China, French Polynesia, Hong Kong SAR, Indonesia, Laos, Macao SAR, Malaysia, Maldives, Marshall Islands, Myanmar, Nepal, New Caledonia, Palestinian Authority, Papa New Guinea, Philippines, Singapore Vietnam

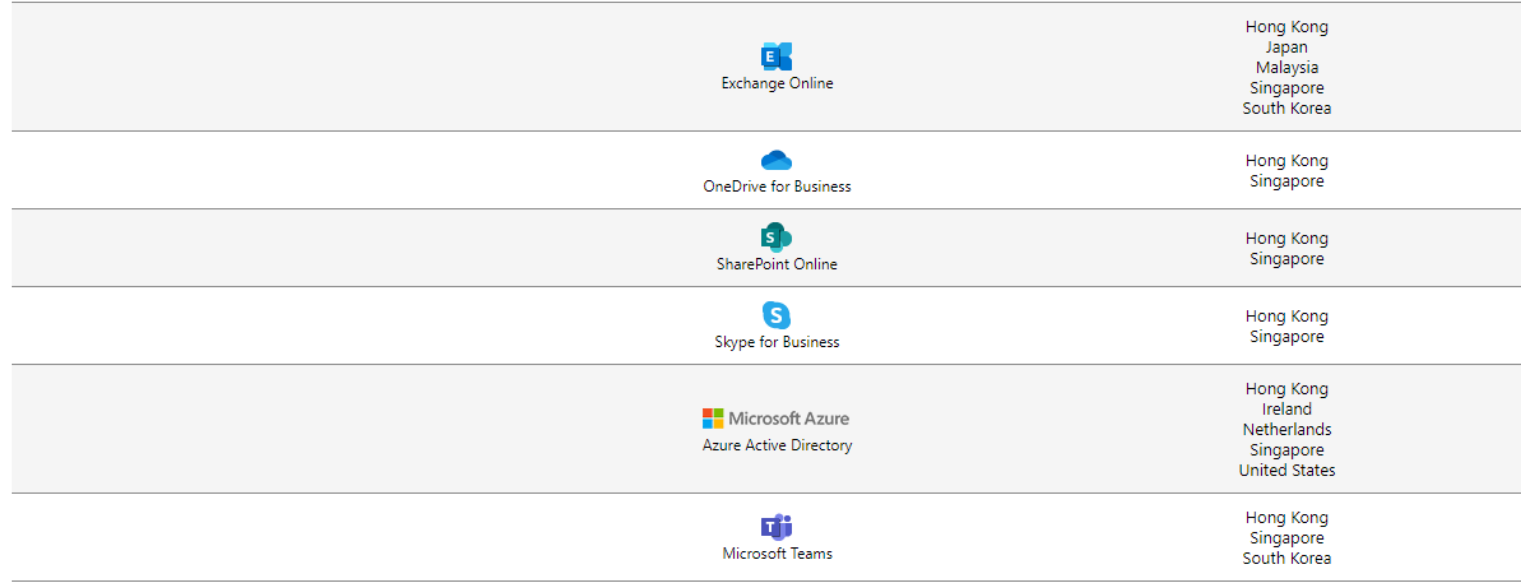

This poses a significant issue for national accounts and balance of payments compilers. If the client is in Asia and is purchasing storage services from a Microsoft data center - which country is the client transacting with? In this case the cloud truly is multi-jurisdictional but our macroeconomic standards dictate that we need to assign production to an economic territory. The above situation does not so much demand a conceptual solution as it demands some form of pragmatic solution. The reason for this pragmatic approach is because it is not realistic (or possible?) to expect Microsoft to provide statistics compilers the value of storage service trade between Hong Kong and Singapore. Especially because Microsoft is probably able to move storage between Hong Kong and Singapore on a frequent basis (daily, weekly, monthly).

What is probably needed in this case is some sort of recommendation that states the production of the services will be attributed to the location where the activity predominately (great than 50 percent) takes place.

It is clear that the wide-scale adoption of cloud computing services is not only pushing the statistical bounds, it is also pushing the conceptual boundaries associated with 
macroeconomic frameworks such as the Balance of Payments and System of National Accounts.

\section{What DifFerence This MaKes To OUR USERS}

The shift to cloud computing will affect the pattern of investment. As described in Figure 3 above, the share of businesses purchasing cloud computing services has increased across all industries among OECD countries. At the same time, the statistics show that the investment in cloud computing is being concentrated industrially. Differences in the rate of adoption can also be found geographically. In figure 4 above we have found that, even among OECD countries, the reported share of businesses purchasing cloud computing services varies by as much as 55 percentage points in 2018 .

The expansion of cloud computing industry can also be seen in the international trade statistics. According to the ICT services complementary grouping recommended by the Partnership on Measuring ICT for Development, an international initiative, the Balance of Payments Services classification (EBOPS) 2010 commodity group 9.2 Computer services includes the CPC codes for cloud computing products. ${ }^{11}$ Across OECD countries, computer services exports have increased rapidly since 2010 , suggesting a possible surge in trade of cloud computing services. From 2010 to 2017, the computer services exports of United States and European countries ( 28 countries) registered average annual growth of 14.3 percent and 7.5 percent respectively.

As described in Figure 8, it is reported that Ireland is the biggest exporter for computing services among OECD countries. The country's exports accounted for 29 percent of the total computing services exports of OECD countries in 2016. Also, the exports represent 43 percent of Ireland's total exports of services for the year (Figure 9). This share is notably high, compared to other major computer services exporters such as Germany (10 percent) and the United States ( 3 percent). This distinctiveness of Ireland's figure could partly be explained by the fact that multinational enterprises credit a large proportion of global computing sales to business units resident in Ireland.

As shown above, current trade statistics provide a rough picture of cloud computing services trade. However, the importance of accurately capturing the trade will grow, as the cloud computing industry expands. Furthermore, the scalability of the service and the mobility between data centers require well timed measurement of the trade. Besides a modified EBOPS classification for the cloud computing services, national accountants would especially need more information on the residency and volume measures for GDP estimates. In this regard, information regarding the import and export prices of cloud computer services are required.

\footnotetext{
${ }^{11}$ UNCTAD. "International Tra de in ICT Services and ICT-enabled Services: Proposed Indicators from the Partnership on Measuring ICT for Development."
} 
Figure 8. Relative Size of Computer Services Export in OECD Countries (2016, in U.S. Dollar)

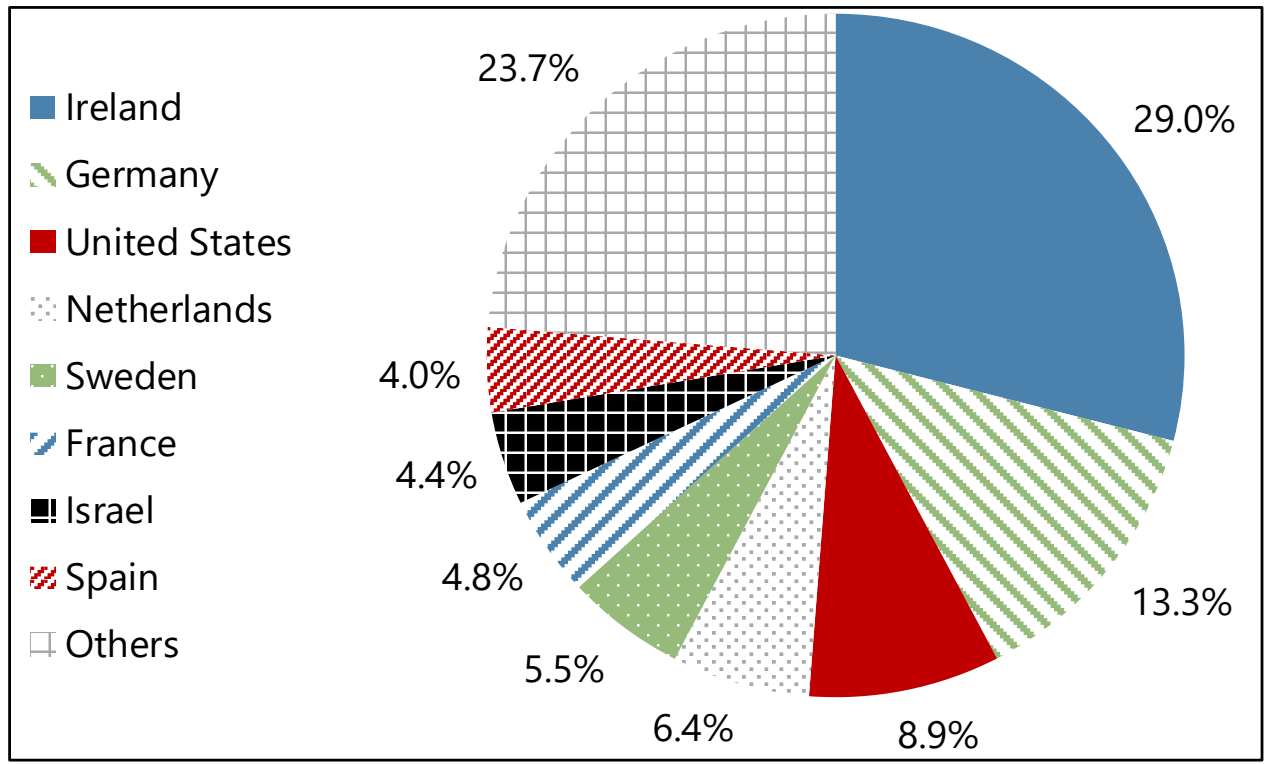

Source: OECD International Trade in Services Statistics.

Figure 9. Computer Services Export Ratio of Major Exporters (Percent)

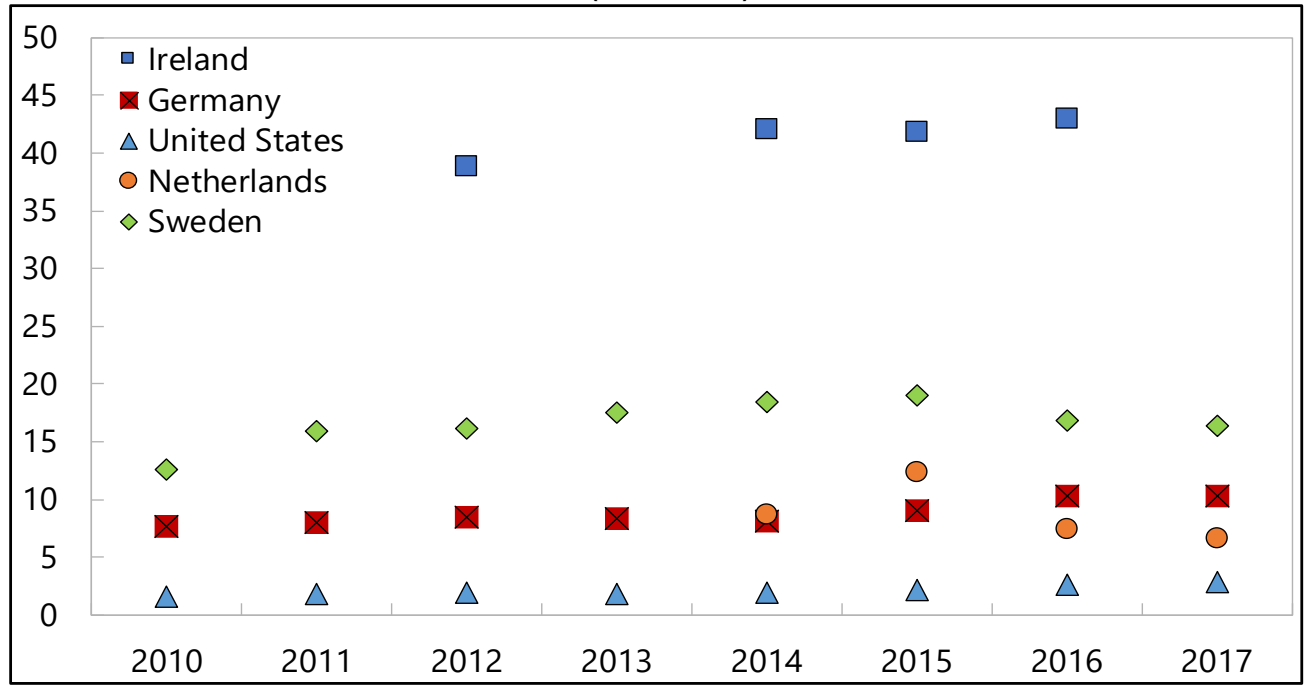

Source: OECD International Trade in Services Statistics.

The shift to cloud computing is also having an impact on goods trade. According to the UNCTAD 2013 World Information Report, servers can be imported under three subcategories of Harmonized System Codes (HS) 8471. Automatic data processing machines and units: 847141,847149 , and 847150. Among them, the largest and most relevant category is HS 847150 , covering computer servers without keyboard and monitors. ${ }^{12}$ Figure 10 shows

${ }^{12}$ Coyle and Nguyen(2019). 
the world share of imports of servers for selected countries. The United States is the dominant importer and its portion has continuously increased since 2014. The import value itself increased more than threefold between 2009 and 2018. Ireland, a location of a number of data centers, has reported significant growth in imports of servers (Figure 11).

Figure 10. Portion of Major Server (HS847150) Importers (Percent)

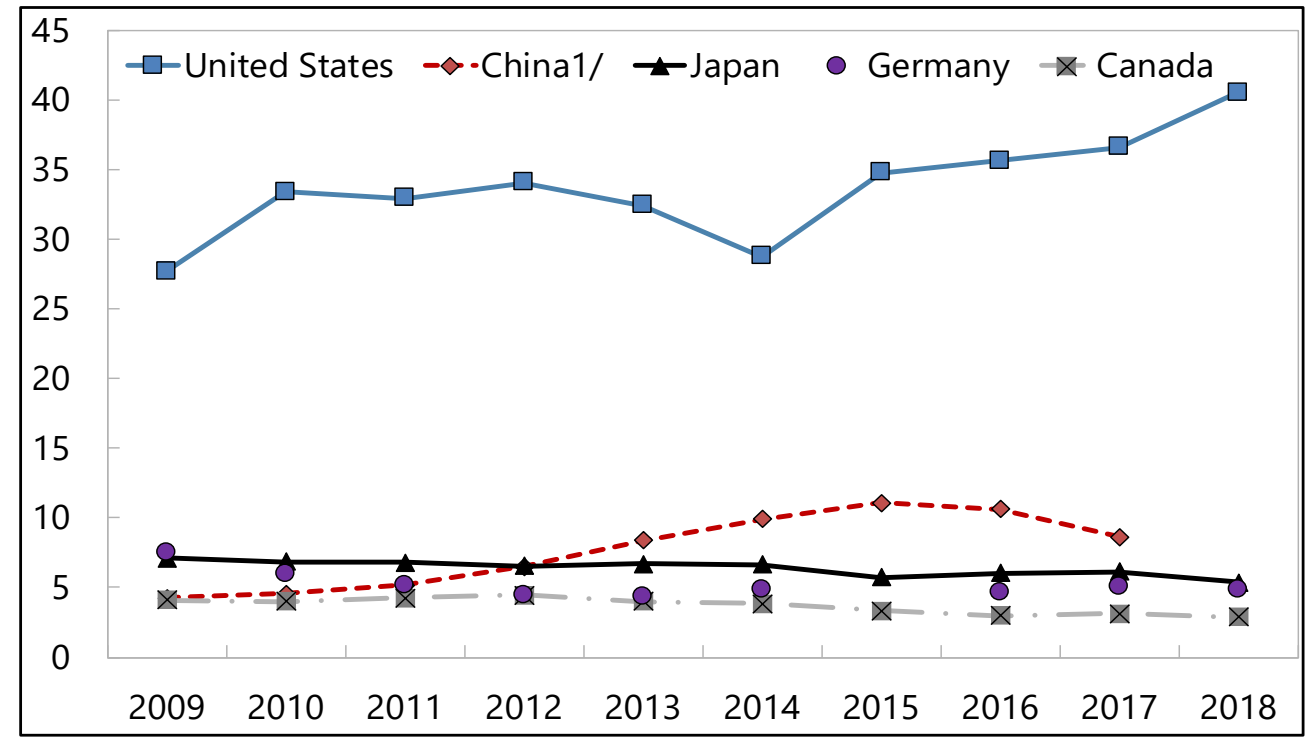

Sources: UN Comtrade.

${ }^{1}$ Include Hong Kong SAR.

Figure 11. Share of Server Imports in Total Imports (Top five countries in 2017, percent)

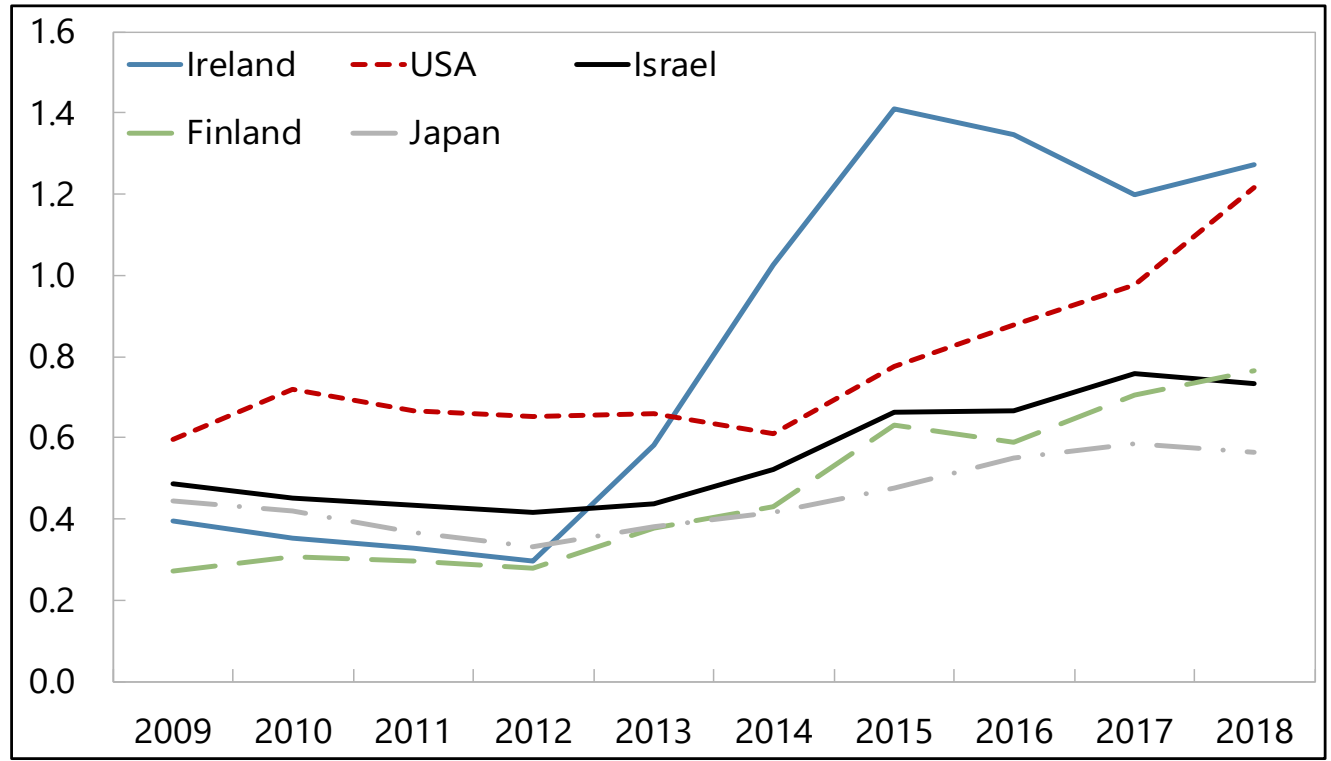

Source: UN Comtrade. 
Investment patterns, trade flows, economy-wide output and value added are some of the key macroeconomic indicators that will be impacted by a wide scale move by businesses and households towards cloud computing. Given the potential size of the shift it is important that national accountants and balance of payments compilers provide granular timely data to users so that they can better understand the significance of the transformation.

\section{Conclusion}

This paper was a first attempt to outline the challenges associated with 'accounting' for a wide-scale sales and purchases of cloud computing services. The paper argued that the delivery of the service is concentrated and global. The potential number of buyers is very large and given the scale and global nature of the activity the implications on macroeconomic indicators and measurement could be large - impacting output, trade, investment and real value added. The paper then noted that most NSOs and IOs are currently not well-placed to measure this transformative change since its measurement requires a new set of tools and instruments. Finally, the paper noted that while most of the challenge is on the measurement side of the border, there are a few conceptual lines that may need to be crossed or moved in order to ensure users are able to interpret and have an appreciation for the changes that are occurring. 


\section{REFERENCES}

"Gartner Forecasts Worldwide Public Cloud Revenue to Grow 17.5 Percent in 2019." Last modified April 2, 2019. https://www.gartner.com/en/newsroom/press-releases/201904-02-gartner-forecasts-worldwide-public-cloud-revenue-to-g.

“Gartner Says Worldwide IaaS Public Cloud Services Market Grew 31.3\% in 2018." Last modified July 29, 2019. https://www.gartner.com/en/newsroom/press-releases/201907-29-gartner-says-worldwide-iaas-public-cloud-services-market-grew-31point3percent-in-2018.

Baer, Andrew, Thomas Hill, Thomas Ponikowski, Bonnie Murphy, Melanie Santiago, and Jason Carnival. 2018. "ISIC 6311 Data processing, hosting, and related services." https://voorburggroup.org/Documents/2018\%20Rome/Papers/1014.pdf.

Byrne, David, Carol Corrado, and Daniel E. Sichel. 2018. "The Rise of Cloud Computing: Minding Your P's, Q's and K's." NBER Working Paper Series. http://www.nber.org/papers/w25188.

Cebula, Beata and Agnieszka Matulska-Bachura. 2018. "ISIC 6311 Data processing, hosting, and related services." https://voorburggroup.org/Documents/2018\%20Rome/Papers/1018.pdf

“Coyle, Diane, David Nguyen. 2018. "Cloud Computing and National Accounting.” ESCoE Discussion Paper 2018-19. https://www.escoe.ac.uk/research/discussion-papers-3/.

Coyle, Diane, David Nguyen. 2019. "Cloud Computing, Cross-Border Data Flows and New Challenges for Measurement in Economics." National Institute Economic Review 249 (August). https://journals. sagepub.com/doi/full/10.1177/002795011924900112.

Dignan, Larry. "Top cloud providers 2019: AWS, Microsoft Azure, Google Cloud; IBM makes hybrid move; Salesforce dominates SaaS.” ZDNet. Last modified August 15, 2019. https://www.zdnet.com/article/top-cloud-providers-2019-awsmicrosoft-azure-google-cloud-ibm-makes-hybrid-move-salesforce-dominates-saas/.

Eurostat. 2018. "Final report of the Task Force 'Price and Volume Measures for Service Activities."'https://unstats.un.org/unsd/nationalaccount/aeg/2018/M12 3b Price Vol ume Services Activities.pdf.

Mathias, Craig. "What is virtualization? Far more than just virtual machines.” Network World. Last modified October 26, 2017. https://www.networkworld.com/article/3234795/what-is-virtualization-definitionvirtual-machine-hypervisor.html.

Miller, Ron. "How AWS came to be." TechCrunch. Last modified July 2, 2016. https://techcrunch.com/2016/07/02/andy-jassys-brief-history-of-the-genesis-of-aws/ 
Rubens, Paul. "What are containers and why do you need them?" CIO. Last modified June 27, 2017. https://www.cio.com/article/2924995/what-are-containers-and-why-do-youneed-them.html.

Tag, Susanna, Anna-Riikka Pitkanen. 2018. "Mini-presentation on Data processing, hosting, and related activities (ISIC 6311) with emphasis on cloud computing." https://voorburggroup.org/Documents/2018\%20Rome/Papers/1016.pdf.

Tal, Itsik, 2018. "ISIC 6311 Data processing, hosting, and related services." https://voorburggroup.org/Documents/2018\%20Rome/Papers/1020.pdf

"UNCTAD. 2015. "International Trade in ICT Services and ICT-enabled Services: Proposed Indicators from the Partnership on Measuring ICT for Development", UNCTAD Technical Notes on ICT for Development. https://unctad.org/en/PublicationsLibrary/tn unctad ict4d03 en.pdf

Weins, Kim. "Cloud pricing comparison: AWS vs. Microsoft Azure vs. Google Cloud vs. IBM Cloud.” InfoWorld. Last modified November 22, 2017. https://www.infoworld.com/article/3237566/cloud-pricing-comparison-aws-vs-azurevs-google-vs-ibm.html. 